\title{
Faktor-Faktor yang Memengaruhi Partisipasi Tenaga Kerja dalam Program Kartu Prakerja
}

\author{
Factors Influencing Labor Participation in the Pre-Employment Card Program \\ Dian Verawati Panjaitan ${ }^{1}$, Nunung Nuryartono ${ }^{2}$, Lukytawati Anggraeni ${ }^{3}$ \\ Departemen Ilmu Ekonomi,Fakultas Ekonomi dan Manajemen, Institut Pertanian Bogor \\ Jalan Agatis, Kampus Dramaga, Bogor 16680, Indonesia \\ Korespondensi: dianpanjaitan@apps.ipb.ac.id
}

[diterima: April 2021-revisi: Mei 2021-diterbitkan daring: Juli 2021]

\begin{abstract}
ABSTRAK
Tujuan awal Kartu Prakerja (Program KP) adalah untuk meningkatkan keterampilan dan mempersiapkan tenaga kerja agar mampu bersaing di dunia kerja. Dengan adanya pandemi Covid-19, tujuannya adalah untuk membantu masyarakat yang terkena dampak pandemi dan mengurangi pengangguran. Setelah satu tahun pelaksanaan program ini, perlu dilakukan analisis yang bertujuan untuk mengetahui sentimen masyarakat terhadap program tersebut dan menganalisis faktor-faktor yang memengaruhi keputusan seseorang untuk mendaftar. Data dari Drone Emprit Academic Open, Sakernas dan metode logit digunakan untuk menjawab tujuan tersebut. Hasil penelitian menunjukkan bahwa masyarakat memberikan sentimen negatif terkait jenis pelatihan dan persyaratan. Faktor-faktor yang memengaruhi keputusan seseorang untuk melamar adalah jumlah jam kerja, pendapatan, usia, pelatihan, status pekerjaan, penggunaan internet. Faktor lainnya adalah persiapan bisnis baru, perubahan pendapatan dan jam kerja, serta tingkat pendidikan. Sentimen negatif masih muncul di beberapa isu terkait jenis pelatihan dan keikutsertaan. PMO perlu meningkatkan cara penyebaran informasi tentang persyaratan dan pendaftaran. Pelatihan bisa lebih murah untuk memungkinkan lebih banyak pelatihan yang diikuti dan menjangkau lebih banyak penerima sesuai anggaran yang tersedia.
\end{abstract}

Kata kunci: prakerja, sakernas, sentimen, penganggguran, pandemi

\begin{abstract}
The initial objective of the Pre-Employment Card (Program KP) is to improve skills and prepare the workforce to be able to compete in the world of work. With the Covid-19 pandemic, the goal is to help people affected by the pandemic and reduce unemployment. After a year of implementing this program, it is necessary to conduct an analysis that aims to determine public sentiment towards the program and analyze the factors that influence a person's decision to register. Data from Drone Emprit Academic Open, Sakernas and the logit method were used to answer the objectives. The results show that the community gives negative sentiments related to the type of training and requirements. The factors that influence a person's decision to apply are the number of hours worked, income, age, training, job status, using the internet. Other factors are preparing for a new business, changes in income and working hours, and education level. The negative sentiment still arises in several issues related to the type of training and enrollment. PMO needs to improve how information is disseminated on requirements and registration. The training can be cheaper to allow more training attended and reach more recipients within the available budget.
\end{abstract}

Keywords: pre-employment, sakernas, sentiment, unemployment, pandemic

JEL Classification: J21, J33, J38 


\section{PENDAHULUAN}

Program Kartu Prakerja (KP) menjadi salah satu solusi yang ditawarkan pemerintah untuk mengatasi masalah pengangguran dan peningkatan kompetensi tenaga kerja terutama lulusan SMA sederajat maupun perguruan tinggi. Sehingga dapat memaksimalkan potensi yang ada sekaligus mengoptimalkan bonus demografi. Tujuan awal dari program KP adalah untuk meningkatkan keterampilan individu dan mempersiapkan angkatan kerja untuk dapat bersaing di dunia kerja. Dengan adanya pandemi Covid-19, tujuannya bertambah untuk membantu masyarakat yang terkena imbas dari pandemi dan mengurangi pengangguran.

Sebelum pandemi, tingkat pengangguran sudah mulai turun dari $5.30 \%$ (tahun 2018) menjadi 5.23\% (tahun 2019). Akan tetapi, dengan adanya pandemi menyebabkan pengangguran kembali meningkat menjadi $7.07 \%$ (tahun 2020). Oleh karena itu, Program KP sebagai salah satu upaya pemerintah untuk mengurangi pengangguran dari sisi penawaran dengan menyiapkan tenaga kerja yang berkualitas.

Tabel 1. Profil Tenaga Kerja Indonesia Periode 2018-2021

\begin{tabular}{lcccc}
\hline \multicolumn{1}{c}{ Jenis Kegiatan } & $\mathbf{2 0 1 8}$ & $\mathbf{2 0 1 9}$ & $\mathbf{2 0 2 0}$ & $\mathbf{2 0 2 1}$ \\
\hline Penduduk Berumur 15 Tahun Ke Atas & $198,126,553.00$ & $201,185,014.00$ & $203,972,460.00$ & $206,708,299.00$ \\
Angkatan Kerja & $133,355,571.00$ & $135,859,695.00$ & $138,221,938.00$ & $140,152,575.00$ \\
a. Tingkat Partisipasi Angkatan Kerja (\%) & 67.31 & 67.53 & 67.77 & 67.80 \\
b. Bekerja & $126,282,186.00$ & $128,755,271.00$ & $128,454,184.00$ & $131,050,523.00$ \\
c. Pengangguran Terbuka *) & $7,073,385.00$ & $7,104,424.00$ & $9,767,754.00$ & $9,102,052.00$ \\
d. Tingkat Pengangguran Terbuka (\%) & 5.30 & 5.23 & 7.07 & 6.49 \\
Bukan Angkatan Kerja & $64,770,982.00$ & $65,325,319.00$ & $65,750,522.00$ & $66,555,724.00$ \\
a. Sekolah & $16,524,382.00$ & $15,943,345.00$ & $15,352,639.00$ & $14,644,442.00$ \\
b. Mengurus Rumah Tangga & $40,382,209.00$ & $40,949,704.00$ & $40,960,652.00$ & $40,577,943.00$ \\
c. Lainnya & $7,864,391.00$ & $8,432,270.00$ & $9,437,231.00$ & $11,333,339.00$ \\
Tingkat Kesempatan Kerja & 94.70 & 94.77 & 92.93 & 93.51 \\
\hline \multicolumn{5}{r}{ Sumber: BPS (2021) } \\
*) Pengangguran Terbuka : Mencari Pekerjaan, Mempersiapkan Usaha, Merasa Tidak Mungkin Mendapat Pekerjaan, Sudah \\
Punya Pekerjaan tetapi belum dimulai bekerja
\end{tabular}

Penduduk Indonesia yang memenuhi persyaratan dapat mendaftar Program KP, memperoleh bantuan dalam bentuk dana yang dapat digunakan untuk kursus atau pelatihan dan insentif dalam bentuk uang setelah mengikuti pelatihan. Program KP dimulai sejak April 2020 dan sudah membuka sebanyak 17 gelombang sampai dengan Juni 2021. Pelatihan yang ditawarkan terdiri dari keterampilan teknis, softskill seperti cara berkomunikasi dan negosiasi. Bahkan terdapat beberapa pelatihan yang memberikan sertifikasi seperti pelatihan sebagai pengasuh anak (baby sitter).

Persyaratan Program KP adalah berusia minimal 18 tahun yang tidak sedang menempuh pendidikan formal. Buruh, wirausaha, pencari kerja, korban PHK, atau lulusan SMA, boleh mendaftar Program Kartu. Masyarakat yang sudah menjadi penerima program bantuan sosial lainnya tidak boleh menerima program ini (Kemenko Perekonomian, 2020). Untuk menjaga efektifitas pelaksanaan program prakerja telah dilakukan beberapa kali evaluasi baik 
oleh Manajemen Pelaksana Prakerja maupun oleh lembaga Independent Telesurvei Cyrus Network tahun 2020. Hasil survei lembaga tersebut menunjukkan bahwa terjadi penurunan jumlah pengangguran setelah mengikuti Program KP. Setelah mengikuti program pelatihan, jumlah yang bekerja turun menjadi $39.85 \%$ yang bekerja naik menjadi $34.6 \%$ dan berwirausaha naik menjadi 25.6\%. Bahkan pada saat pelaksanaan Sakernas Agustus 2020, ditambahkan pertanyaan terkait dengan prakerja ketika program ini baru berjalan selama 5 bulan (April-Agustus 2021), 2 bulan efektif dari gelombang 1 sampai gelombang 3, dan jumlah penerima kurang dari 50\%. Akan tetapi, hasil survei ini sangat penting sebagai bahan evaluasi program, melengkapi survei yang diadakan sebelumnya.

Berdasarkan hasil Sakernas 2020, penerima kartu prakerja adalah mayoritas laki-laki yang tinggal di perkotaan, berusia muda, pendidikan SMA ke atas (91\%). Sebanyak $45 \%$ pengangguran pada bulan Agustus, atau 5 bulan sejak program diluncurkan, menyatakan tahu tentang Program KP. Alasan utama mereka mengikuti Program KP adalah untuk meningkatkan keterampilan kerja (skill) dan mencari insentif. Sebanyak $88.9 \%$ penerima Kartu Prakerja yang menyelesaikan pelatihan mengatakan Program KP meningkatkan keterampilan kerja mereka. Insentif Kartu Prakerja umumnya digunakan untuk memenuhi kebutuhan sehari-hari (81\%), ditabung (33\%), dan modal usaha (23\%).

Selain survei yang telah dilakukan, perlu diketahui bagaimana opini publik terkait program prakerja dengan menggunakan data yang bersumber dari twitter karena pengguna media ini masuk dalam peringkat 5 terbesar di dunia. Twitter termasuk dalam media sosial yang paling sering digunakan oleh pengguna internet di Indonesia. Pengguna twitter banyak membicarakan isu-isu hangat berbagai bidang, baik sosial, ekonomi, maupun politik seperti kebijakan pemerintah. Pro kontra yang hangat dibincangkan di twitter mengenai kartu prakerja menjadi hal yang perlu diperhatikan untuk penyempurnaan kebijakan tersebut (Anggraini et al., 2021). Menurut (Anggraini et al., 2021), komentar masyarakat pengguna twitter terhadap kartu Prakerja lebih banyak menuai komentar negatif. Hasil analisis berdasarkan data selama periode September-Oktober 2020 atau selama pembukaan gelombang 7-10, menunjukkan bahwa sebanyak $52.87 \%$ komentar memiliki sentimen negatif. Hal tersebut tentunya perlu menjadi perhatian, dimana masyarakat lebih banyak menulis komentar negatif terhadap kebijakan dan pelaksanaan Program KP. Maka, pemerintah dapat terus melakukan evaluasi lebih lanjut terhadap kekurangan dalam implementasi kebijakan kartu prakerja. Perlu dilakukan analisis sentimen masyarakat setelah 1 tahun pelaksanaan kartu Prakerja dan bersamaan dengan pembukaan gelombang 7. Untuk dapat mengetahui bagaimana efektivitas penggunaan media terhadap sosialisasi dan komunikasi Program KP (Handayani \& Rachman, 2020).

Hasil Sakernas 2020 menunjukkan bahwa sebanyak $77.40 \%$ responden tidak mengetahui tentang Prakerja padahal sudah berjalan selama 5 bulan. Mereka yang tahu tentang program ini tidak semuanya ikut mendaftar, hanya $6.20 \%$ yang mendaftar. Hal ini kemungkinan karena mereka tidak memenuhi persyaratan utama yaitu sudah menerima bantuan sosial dari pemerintah dan atau sedang mengikuti pendidikan formal. Faktor ini belum dapat dibuktikan karena keterbatasan akses terhadap data penerima bantuan sosial dan responden Sakernas 2020. 
Analisis hanya dapat dilakukan untuk mengetahui faktor demografi dan non demografi dalam memengaruhi keputusan mereka untuk mendaftar atau tidak Program KP. Untuk mengetahui faktor yang memengaruhi kecenderungan responden untuk mendaftar berdasarkan kelompok pekerjaan (formal-informal), lokasi geografis (kota-desa), dan tingkat pendidikan sehingga dapat diketahui jenis pelatihan yang dibutuhkan.

Berbagai studi telah dilakukan terkait dengan sentimen Program KP diantaranya Anggraini et al (2021) dan Handayani \& Rachman (2020). Sedangkan penelitian mengenai faktor keikutsertaan dalam Program KP baru dilakukan oleh Lusianingrum et al., (2020) terhadap 150 orang di Provinsi Banten dengan metode SEM. Tidak seperti penelitian sebelumnya, penelitian ini menggunakan data Sakernas periode Agustus 2020 untuk 32 provinsi di Indonesia dengan metode logit. Sehingga analisis dilakukan pada level nasional dan tidak hanya satu provinsi atau wilayah tertentu saja. Begitu pula dengan analisis sentimen terhadap Program KP yang sebelumnya dilakukan Anggraini et al (2021) menggunakan data dari twitter pada periode September-Oktober 2020. Sedangkan penelitian ini menggunakan data dari twitter hanya sampai pada periode April 2020 sampai Juni 2021. Penelitian ini juga memastikan bahwa twit-twit tidak bersumber dari akun palsu dan atau robot dengan menggunakan bot score.

Program KP merupakan bagian dari peningkatan kualitas human capital di Indonesia melalui pelatihan. Penelitian terkait peran human capital di era pandemi menjadi penting untuk dilakukan karena banyaknya pekerja yang mengalami Pemutusan Hubungan Kerja (PHK). Program ini diberikan kepada pencari kerja atau pekerja untuk mendapatkan layanan pelatihan skilling, up-skilling, re-skilling, dan sertifikasi kompetensi kerja. Keberhasilan program ini tentu saja dipengaruhi oleh peserta yang mengikutinya, sehingga perlu diketahui faktor-faktor apa saja yang memengaruhi keikutsertaan seseorang dalam Program KP agar multiplier efeknya berlaku jangka panjang. Berdasarkan latar belakang tersebut, tujuan dari penelitian ini adalah untuk 1) mengetahui sentimen masyarakat terhadap Program KP setelah 1 tahun pelaksanaannya, dan 2) menganalisis faktorfaktor yang memengaruhi keputusan seseorang untuk mendaftar kartu Prakerja.

\section{LANDASAN TEORI}

\section{Pendidikan Sebagai Barang Publik}

Pendidikan merupakan bagian dari barang publik, dimana setiap masyarakat mempunyai hak yang sama untuk mendapatkan pendidikan dan pengajaran seperti dituangkan dalam amanat Undangundang Dasar 1945, Pasal 31. Pemerintah wajib menyediakan akses dan kesempatan belajar bagi semua penduduk Indonesia (Arwildayanto et al., 2018). Sehingga kebijakan di bidang pendidikan juga merupakan kebijakan publik dimana ciricirinya: a) kebijakan tersebut dibuat oleh negara/lembaga yang berkaitan dengan eksekutif, yudikatif dan legislatif, b) kebijakan ditujukan untuk mengatur kehidupan bersama, dan c) mengatur masalah bersama. Pada era digitalisasi dan industrialisasi, untuk menghadapi kompetisi global, kebijakan pendidikan perlu mendapatkan prioritas utama untuk ditelaah secara kritis dan komprehensif. Menurut Olssen, W., Codd, J., and O'neil (1994), kebijakan pendidikan di abad ke 21 adalah kunci untuk keamanan global, keberlanjutan dan kelangsungan hidup, serta kebijakan 
pendidikan adalah inti dari misi global tersebut.

Pemerintah telah melakukan beragam kebijakan pendidikan diantaranya, pemberian dana Bantuan Operasional Sekolah (BOS), Wajib Belajar 9 tahun, dan peningkatan standar penghasilan Guru dengan adanya sertifikasi guru, serta pemberian bantuan pendidikan (Beasiswa) untuk peningkatan Kompetensi guru, dan sebagainya (Taufiqurakhman, 2014). Kebijakan publik biasanya dibuat oleh pemerintah dan memberikan dampak yang besar dan luas pada publik (masyarakat), misalnya kebijakan Sistem Pendidikan Nasional (Sisdiknas) dan Ujian Akhir Nasional (UAN). Konsep kebijakan publik dapat dipandang sebagai tindakan-tindakan yang dilakukan pemerintah dan atau keputusankeputusan pemerintah yang mempunyai tujuan atau sasaran tertentu (Sutapa, 2008).

Sehingga Program KP merupakan salah satu kebijakan pendidikan dari pemerintah Indonesia untuk meningkatkan kemampuan tenaga kerja agar dapat bersaing di era global dan digital saat ini.

\section{Teori Modal Manusia (Human Capital)}

Teori modal manusia merupakan kemampuan yang ada pada diri manusia, seperti pengetahuan dan keterampilan. Modal yang dimaksud merupakan pengetahuan, kompetensi, sikap, kesehatan, dan sifat (Rastogi, 2002). Modal manusia merupakan pengetahuan dan keterampilan yang didapatkan melalui berbagai aktifitas pendidikan seperti sekolah, kursus, pelatihan melalui akumulasi suatu proses tertentu (Alan et al, 2008). Sedangkan menurut Romer (1999), human capital merupakan sumber mendasar dari produktivitas ekonomi. Frank \& Bemanke (2007) berpendapat bahwa human capital adalah perpaduan antara pendidikan, pengalaman, pelatihan, keterampilan, kebiasaan, dan kesehatan yang memengaruhi produktivitas manusia. Semakin banyak jumlah manusia atau tenaga kerja maka produktivitas semakin tinggi. Pendidikan dan pelatihan yang didapatkan akan meningkatkan kemampuan dan keterampilannya, sehingga produktivitas dan nilai tambah juga akan meningkat.

\section{Penelitian Terdahulu}

Sejak pandemi, tujuan Program KP tidak hanya untuk meningkatkan kualitas tenaga kerja melalui pelatihan tapi juga untuk membantu masyarakat yang terkena dampak. Terutama untuk masyarakat yang tidak dapat memperoleh bantuan sosial lainnya. Sehingga penerima program ini bisa siapa saja kecuali yang sudah menerima bantuan sosial lainnya dan terdaftar sebagai mahasiswa. Akan tetapi, timbul permasalahan terkait belum adanya data yang valid untuk target penerima Program KP yang bersifat terbuka yang dapat menghambat pencapaian tujuan program kartu prakerja.

Beberapa penelitian sebelumnya terkait dengan Program KP belum mengidentifikasi faktor-faktor apa saja yang memengaruhi masyarakat Indonesia untuk berpartisipasi dalam program ini. Penelitian yang dilakukan oleh Lusianingrum et al., (2020) mengenai bahwa faktor-faktor yang dapat memengaruhi keputusan mengikuti pelatihan hanya pada 150 wanita penerima insentif di Provinsi Banten. Sehingga penelitian ini untuk mengetahui faktor-faktor yang memengaruhi partisipasi seseorang dalam Program KP dengan sampling adalah seluruh masyarakat Indonesia dari data Sakernas. Hal ini karena program ini berlaku terbuka untuk seluruh masyarakat dari 32 provinsi kecuali dua golongan yang dijelaskan sebelumnya. 
Menurut Rawie \& Samputra (2020), alternatif kebijakan yang memberikan manfaat besar dan biaya kecil adalah dengan memberikan pelatihan kepada para pengangguran. Jika hanya memberikan jaminan sosial tanpa adanya pelatihan kepada pengangguran tidak serta merta meningkatkan rata-rata pendapatan nasional. Sehingga Program KP yang terbuka bagi siapa saja (pekerja dan pengangguran) diharapkan dapat menurunkan tingkat pengangguran jika tepat sasaran penerima dari program ini. Jika dapat diketahui faktorfaktor yang memengaruhi seseorang untuk mendaftar program ini maka dapat disesuaikan jenis program pelatihan, langkah selanjutnya setelah pelatihan berdasarkan rencana masing-masing penerima program. Bagi penerima yang merupakan wirausaha dapat dihubungkan dengan fasilitas kredit dan bagi pekerja dapat dihubungkan dengan perusahaan-perusahaan yang sesuai dengan kompetensinya masing-masing. Program KP yang berbasis online ini dapat bekerjasama dengan situs-situs lowongan kerja untuk mempertemukan antara demand dan supply tenaga kerja.

Penelitian terdahulu mengenai sentimen terhadap Program KP dilakukan oleh Anggraini et al., (2021) dengan metode klasifikasi Naive Bayes terhadap komentar masyarakat pengguna twitter selama pembukaan gelombang 7-10. Tentu saja setelah satu tahun implementasi program ini perlu diketahui bagaimana pendapat/ pandangan masyarakat sebagai bahan masukan untuk perbaikan kedepan. Menurut Handayani \& Rachman (2020), masyarakat secara aktif melakukan pencarian informasi terhadap Program KP dengan untuk memperoleh manfaat sebagai solusi mengatasi masalah ekonomi yang dihadapi akibat pandemi. Hal ini menunjukkan antusias masyarakat terhadap Program KP yang memiliki misi ganda selama pandemi.

\section{METODE}

\section{Jenis dan Sumber Data}

Data yang digunakan adalah data primer dan data sekunder untuk menjawab tujuan penelitian. Data primer bersumber dari hasil survei Sakernas Agustus 2020, dan Drone Emprit Academic Open yang merupakan sebuah sistem yang berfungsi untuk memonitor serta menganalisa media sosial dan platform online yang berbasis teknologi big data. Sedangkan data sekunder diperoleh dari laporan Project Management Operation/ PMO.

\section{Metode Analisis}

\section{Analisis Sentimen}

Analisis sentimen bertujuan untuk mendapatkan berbagai sumber data dari internet dan beragam platform media sosial. Sehingga dapat diperoleh opini dari pengguna yang terdapat pada platform tersebut. Setiap hari, internet dibanjiri oleh miliaran data dari berbagai sumber yang berperan sebagai alat yang dapat menghubungkan seluruh data tersebut. Dengan begitu, perusahaan dapat memperoleh masukan inti dari pengguna atau konsumen secara efisien. Analisis sentimen merupakan salah satu bidang dari Natural Languange Processing (NLP) yang membangun sistem untuk mengenali dan mengekstraksi opini dalam bentuk teks. Informasi berbentuk teks saat ini banyak terdapat di internet dalam format forum, blog, media sosial (twitter), serta situs berisi review. Dengan bantuan analisis sentimen, informasi yang tadinya tidak terstruktur dapat diubah menjadi data yang lebih terstruktur. Data sentimen tersebut bersifat positif dan negatif dimana sentimen positif yaitu 
sentimen dimana pengguna memberikan komentarnya dengan memberikan penilaian secara positif atau memberikan keterangan bahwa aplikasi ini baik atau mempunyai kepuasan untuk menginstal aplikasi tersebut. Sedangkan sentimen negatif merupakan sentimen sebaliknya dari sentimen positif yaitu pengguna memberikan komentarnya dengan memberikan ketidakpuasan terhadap aplikasi tersebut. Metode ini digunakan Drone Emprit Academic Open sehingga penulis menggunakan crawling data twitter yang bersumber dari website ini.

\section{Model Logit}

Model logit adalah model regresi nonlinear yang menghasilkan sebuah persamaan dimana variabel dependen bersifat kategorikal. Model ini digunakan untuk menjawab tujuan ke-dua yaitu menganalisis pengaruh faktor demografi dan non demografi terhadap keputusan mendaftar kartu Prakerja. Analisis regresi logistik biner ini untuk mengetahui 2 hal yaitu keputusan mendaftar atau tidak mendaftar kartu Prakerja. Analisis regresi logistik dilakukan melalui tahapan reduksi peubah untuk masing-masing variabel dengan menggunakan uji-t. Model regresi logistik yang digunakan adalah (Hosmer dan Lemeshow, 1989).:

$$
Y i=\ln \left[\frac{P i}{1-P i}\right]=\alpha_{0}+\alpha_{1} A+\alpha_{2} B+\alpha_{3} C+\alpha_{4} D+\alpha_{5} E+\alpha_{6} F+\alpha_{7} G+\alpha_{8} H
$$

Dimana:

Yi : probabilitas responden (mendaftar atau tidak Program KP)

$\alpha_{0} \quad:$ konstanta

$\boldsymbol{\alpha}_{\mathbf{1}}-\boldsymbol{\alpha}_{\mathbf{8}}$ : koefisien regresi logistik

Rasio odds dapat digunakan untuk memudahkan interpretasi koefisien. Rasio odds adalah ukuran yang memperkirakan berapa besar kecenderungan peubah-peubah penjelas (variabel bebas) terhadap peubah respon (variabel tak bebas) (Hosmer dan Lemeshow, 1989). Jika suatu variabel bebas mempunyai tanda koefisien positif, maka nilai rasio odds-nya lebih besar dari satu. Sebaliknya jika tanda koefisiennya negatif, maka nilai rasio odds-nya lebih kecil dari satu.

Pada penelitian ini, variabel terikat yang digunakan yaitu keputusan individu untuk mendaftar atau tidak mendaftar
Program KP. Sedangkan variabel bebasnya terdiri dari faktor individu (jam kerja, pendapatan, umur, pendidikan, training) dan faktor lainnya seperti jenis pekerjaan (formal, informal), penggunaan internet dalam pekerja dimana individu yang terbiasa menggunakan internet lebih cepat mendapatkan informasi tentang Program KP. Seseorang yang sedang mempersiapkan usaha baru akan lebih tertarik untuk mendaftar Program KP untuk mengikuti pelatihan yang sesuai dengan kebutuhan. Serta individu yang berkurang jam kerja ataupun pendapatannya selama pandemi akan lebih termovitasi untuk mendaftar Program KP. Pemilihan semua variabel tersebut berdasarkan data yang tersedia dalam Sakernas periode Agustus 2020. Model empiris yang digunakan dalam penelitian ini dapat dimodelkan sebagai berikut: 


$$
\begin{aligned}
\log \frac{P\left(Y_{i}\right)}{1-P\left(Y_{i}\right)}=g\left(Y_{i}\right)= & \alpha_{0}+\alpha_{1} \text { jam kerja }_{i}+\alpha_{2} \text { pendapatan }_{i}+\alpha_{3} \text { umur }_{i}+\alpha_{4} \text { training }_{i}+\alpha_{5} \text { bekerja }_{i} \\
& +\alpha_{6} \text { formal }_{\text {informal }_{i}}+\alpha_{7} \text { internet }_{i}+\alpha_{8} \text { jam kerja berubah }_{i}+\alpha_{9} \text { usaha baru }_{i} \\
& +\alpha_{10} \text { pendapatan kerja bertambah }_{i}+\alpha_{11} \text { pendidikan }_{i}
\end{aligned}
$$

Dimana:

$$
\begin{gathered}
\text { Yi } \quad \text { 1: Mendaftar Program KP } \\
\text { 0: Tidak Mendaftar Program } \\
\text { KP }
\end{gathered}
$$$$
\text { Jam kerja = Jam kerja/minggu }
$$$$
\text { Pendapatan }=\text { Pendapatan }(\mathrm{Rp} / \text { bulan })
$$$$
\text { Umur = Umur (tahun) }
$$

formal_informal $=1$ : formal

$$
\text { 0: informal }
$$

Internet $=1$ : menggunakan internet pada pekerjaan

0 : tidak menggunakan internet pada pekerjaan

Training $=1$ : sedang mengikuti training

0: sedang tidak mengikuti training

Jam_kerja_bertambah =

1: jam kerja bertambah dibandingkan Februari 2020

0 : jam kerja berkurang dibandingkan Februari 2020

Usaha_baru $=$

1 :sedang mempersiapkan usaha baru

0:tidak sedang mempersiapkan usaha baru

Pendapatan_kerja_bertambah =

1: pendapatan bertambah dibandingkan

Februari 2020
0: pendapatan berkurang dibandingkan Februari 2020

Pendidikan $=$

1: Tidak sekolah-SD-SMP

2: SMA-SMK

3: Diploma-PT

\section{HASIL DAN PEMBAHASAN}

\section{Sentimen Masyarakat Terhadap Program KP}

Google dapat menjadi salah satu sumber utama untuk mencari informasi terkait kartu Prakerja bahkan pada saat pendaftaran tidak dibuka. Tingkat pencarian semakin meningkat setiap kali pembukaan gelombang kartu Prakerja yang mengindikasikan minat dan keingintahuan yang tinggi. Masyarakat di luar Pulau Jawa seperti di Sulawesi Barat, Bengkulu, Gorontalo, dan Bangka Belitung yang lebih banyak melakukan pencarian dengan kata kunci Prakerja melalui Google selama periode 11 April 2020-13 Juni 2021.

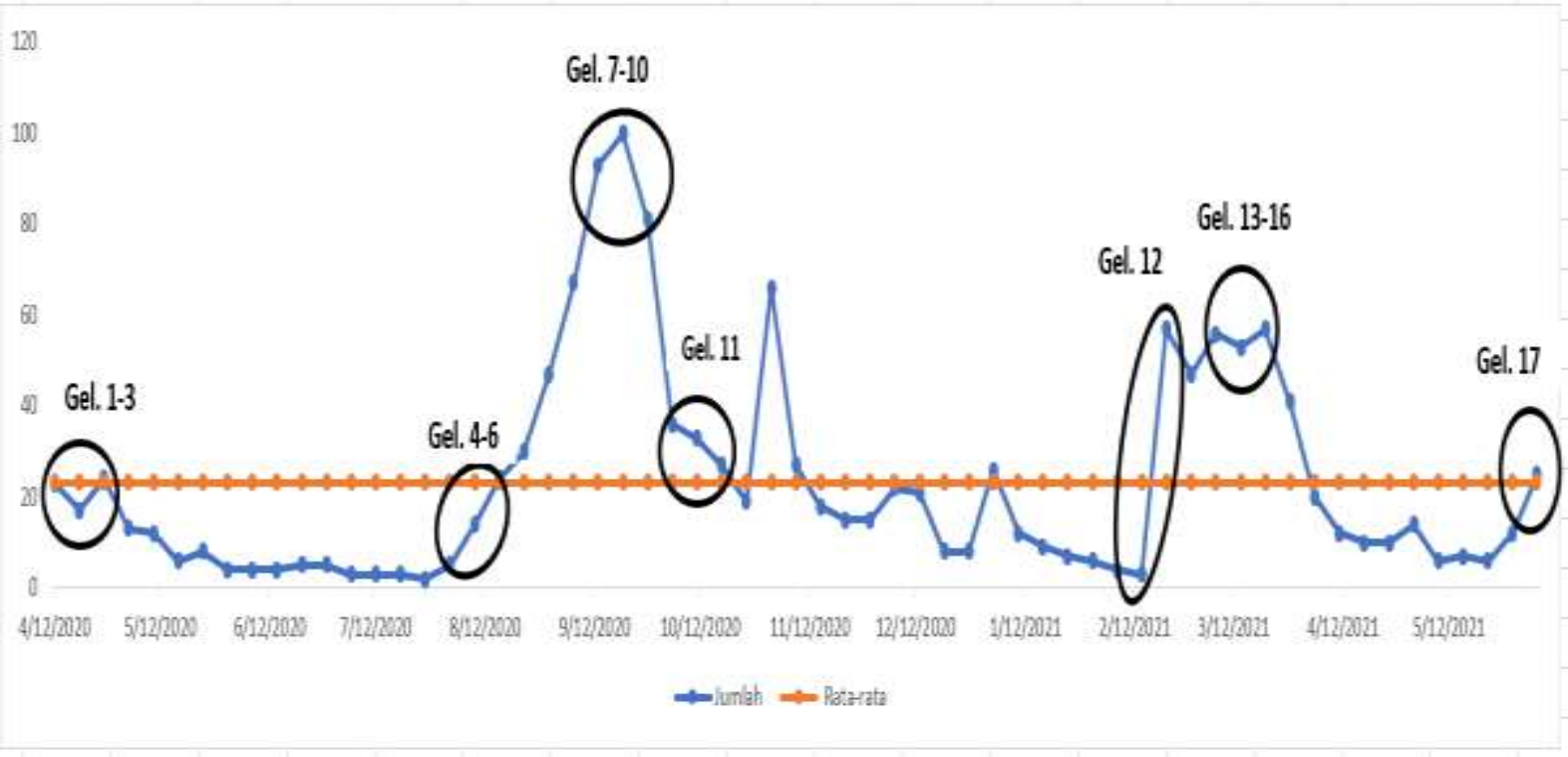



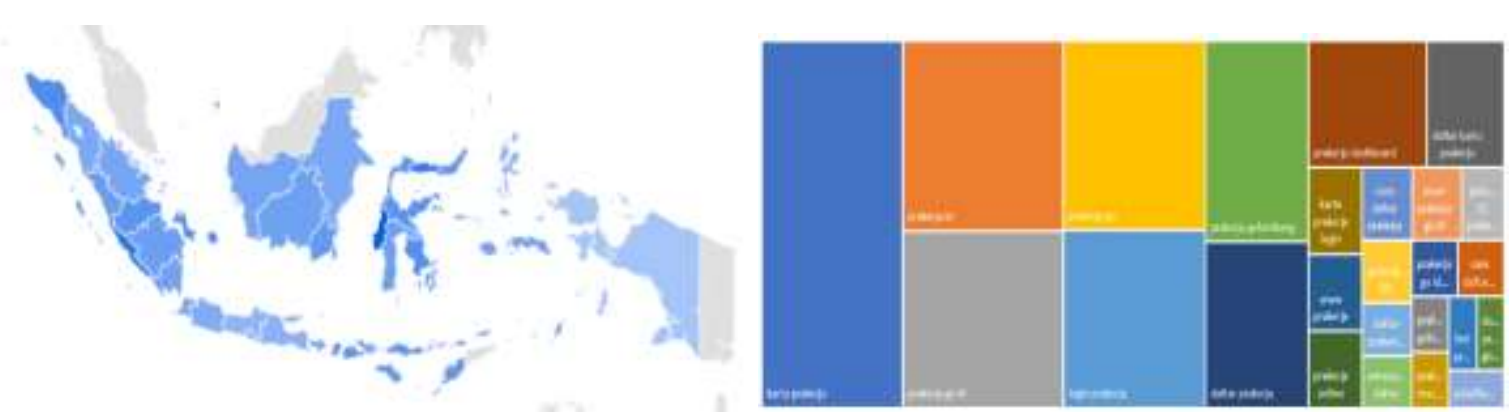

Sumber: google trends (2021), diolah

Gambar 1. Tren Penelusuran Informasi Kartu Prakerja di Media Internet Periode April 2020-Juni 2021

Berdasarkan data dan analisis dari dimana semakin besar ukuran font kata Drone Emprit Academic Open, dilakukan dalam wordcloud, berarti semakin sering kata analisis sentimen yang dimulai dari tersebut digunakan dan berkaitan dengan kata memberikan highlight pada kata-kata yang "prakerja". Kata yang sering digunakan paling sering muncul pada suatu kumpulan bersamaan dengan kata "prakerja" teks (wordcloud). Wordcloud memberikan diantaranya yaitu gelombang, program, representasi dari data teks secara visual dibuka, alumni, dan sukses.
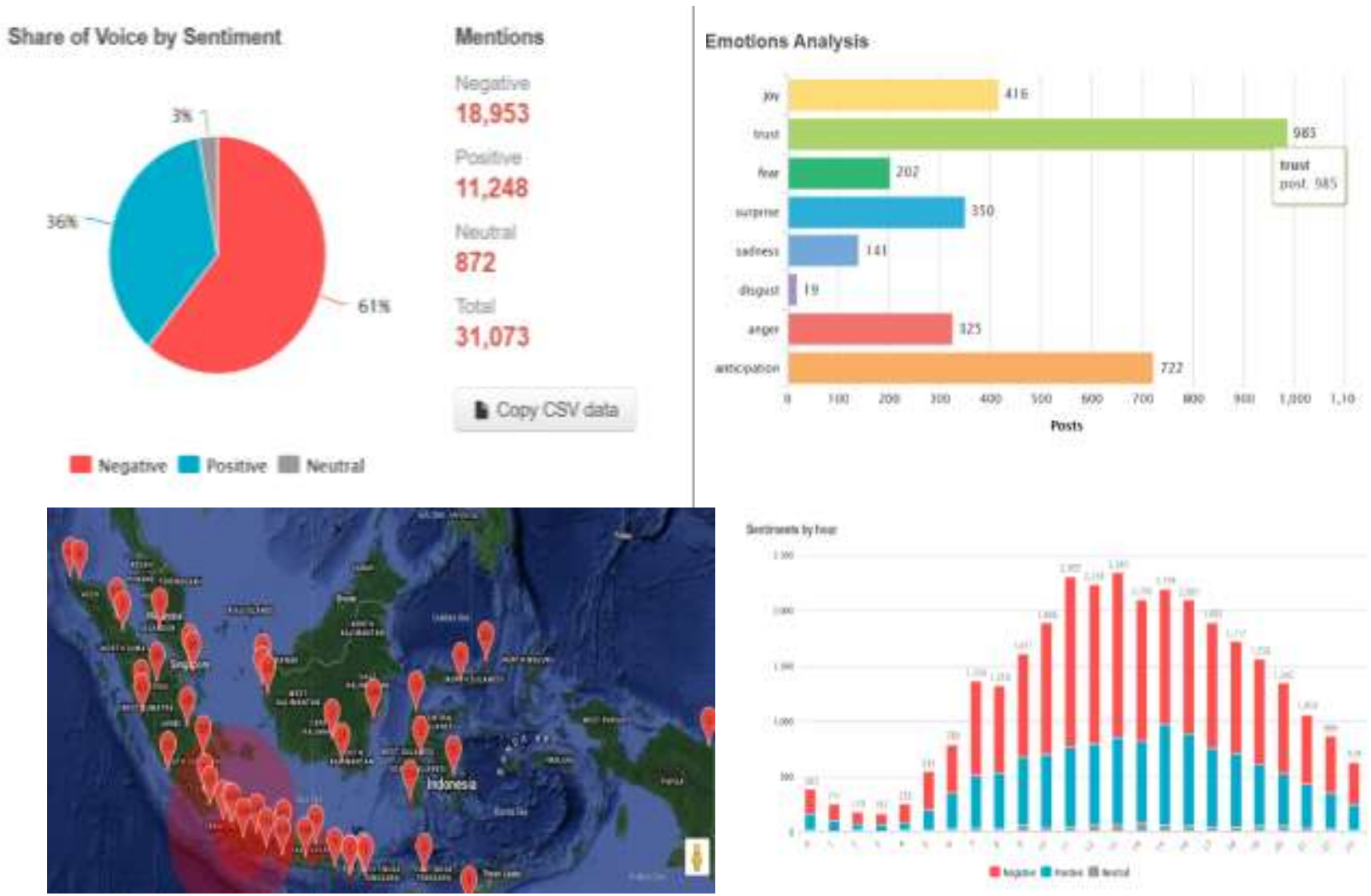

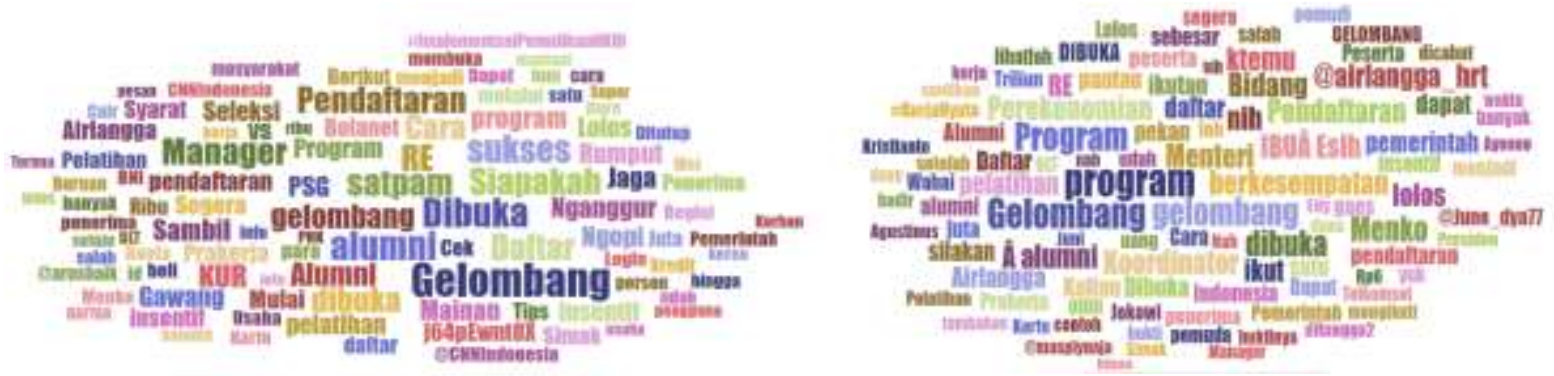

Sumber: Drone Emprit Academic Open (2021)

Gambar 2. Sentimen Masyarakat Terhadap Kartu Prakerja Berdasarkan Data Twitter Periode 3 Mei 2020-15 Juni 2021

Dengan adanya hasil Bot Score, dapat dipastikan bahwa twit-twit yang tidak bersumber dari akun palsu dan atau robot, sehingga dapat dilakukan analisis selanjutnya. Kartu Prakerja yang Bersumber dari Twitter Setelah membentuk wordcloud, didapatkan jumlah data sebanyak 31073 tweet selama periode 3 Mei 2020-15 Juni 2021. Kemudian, data dilabelkan menjadi sentimen positif dan sentimen negatif berdasarkan skor sentimennya. Analisis sentimen dari data Drone Emprit Academic Open sejak pertama kali Program KP ini diluncurkan lebih banyak yang sentimen negatif $(61 \%)$ atau 18 953. Sisanya adalah sentimen positif $(11248=36 \%)$ dan netral $(872=3 \%)$. Sehingga dapat diketahui bahwa masyarakat cenderung memberi sentimen/ komentar negatif terhadap topik "prakerja" ketika membicarakan topik prakerja. Sentimen masyarakat tersebut tentu dapat dijadikan pertimbangan bagi pemerintah untuk mengkaji lebih dalam mengenai implementasi Kartu Prakerja atau menjawab isu-isu yang berkembang di masyarakat. Dengan mengetahui isu-isu tersebut,

pemerintah dapat langsung mengklarifikasi dan atau mencari cara untuk menyelesaikannya. Salah satu contoh sentimen negatif adalah terkait dengan jenis pelatihan mancing yang pada kenyataannya adalah pelatihan bisnis perikanan karena terjadi salah dalam penerjemahan menjadi mancing. Hal ini langsung ditanggapi oleh Direktur Eksekutif Manajemen Pelaksana Kartu Prakerja. Melalui tweet yang ada dapat diketahui kelebihan dan kekurangan dalam implementasi kebijakan kartu prakerja. Sehingga, dapat dilakukan evaluasi lebih lanjut agar manfaat Program KP dapat dirasakan oleh masyarakat secara lebih luas.

Sementara itu, Anggraini et al., (2021) yang menganalisis sentimen dan pengujian metode klasifikasi Naive Bayes terhadap komentar masyarakat pengguna twitter untuk Kartu Prakerja. Hasilnya menunjukkan bahwa sebanyak $52.87 \%$ komentar memiliki sentimen negatif sehingga pemerintah harus terus melakukan evaluasi lebih lanjut terhadap kekurangan dalam implementasi kebijakan kartu prakerja. 


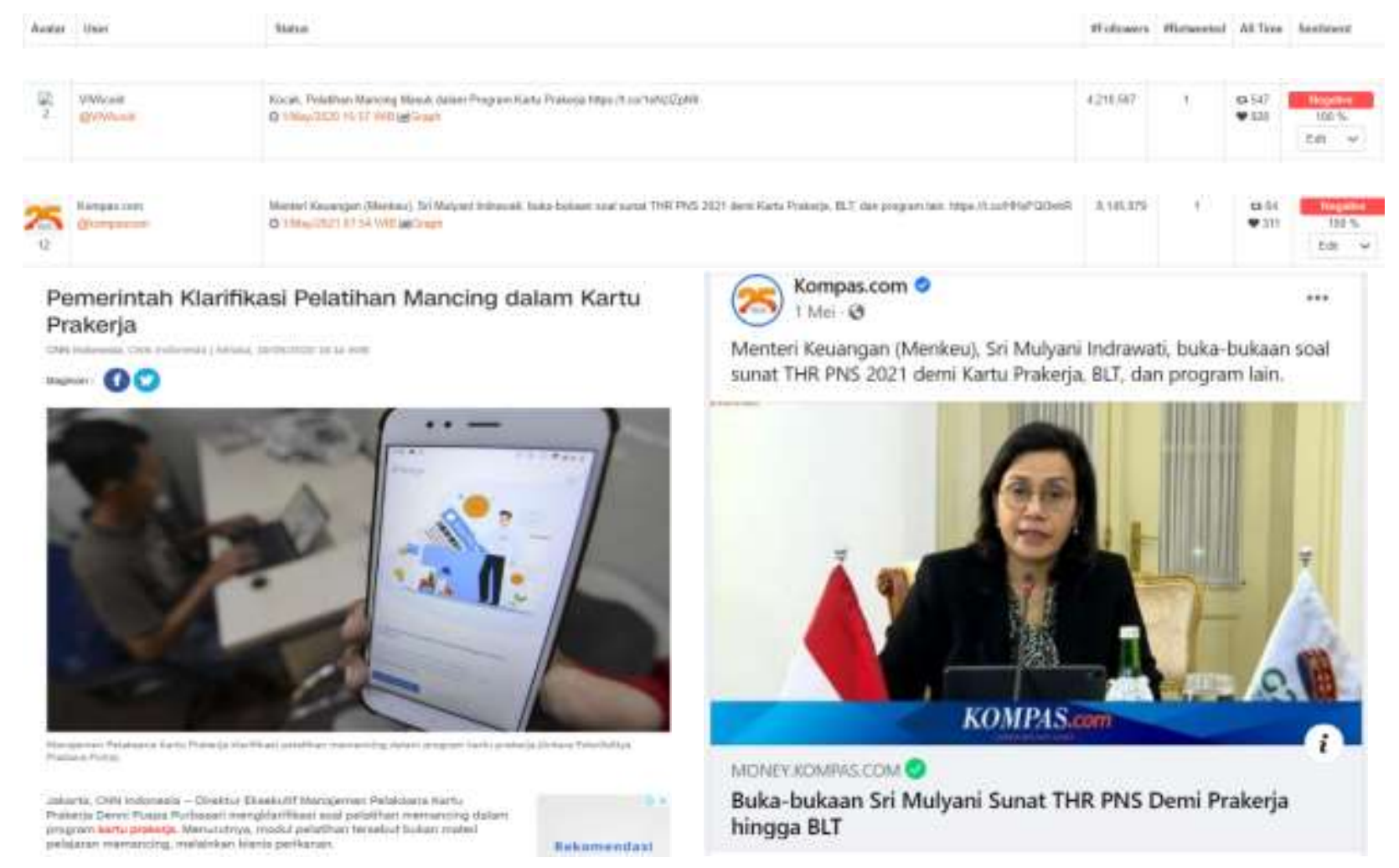

Gambar 3. Contoh Sentimen Prakerja di Twitter

Selain itu, hal yang perlu dipertimbangkan kembali adalah jenis pelatihan yang ditawarkan oleh prakerja sebenarnya dapat diakses dan dipelajari dari media youtube secara gratis. Masyarakat yang ingin mengetahui, misalnya bagaimana cara membuat donat dapat dicari di youtube atau di google. Selain itu, belum ada keharusan bagi penerima insentif untuk melaporkan kembali apa yang akan dan mereka lakukan setelah menerima pelatihan atau insentif. Jika dalam persyaratan pendaftaran ada semacam proposal sederhana terkait dengan rencana memulai bisnis, rencana pekerjaan, atau rencana mengembangkan usaha maka dapat dipetakan pelatihan yang dibutuhkan seperti apa. Setelah mendapatkan pelatihan, penerima insentif dapat memulai melakukan rencana sesuai dengan proposal yang dibuat dan secara berkala harus melaporkan perkembangannya.

Smeru (2020) menyebutkan bahwa mayoritas peserta tidak memilih pelatihan secara saksama karena tidak mengetahui rencana usaha atau pekerjaannya. Dengan adanya proposal atau rencana usaha maka pemilihan pelatihan disesuaikan dengan skema yang telah disusun. Selain itu, ada peserta program KP yang tidak tepat untuk mengikuti pelatihan tetapi sangat membutuhkan bansos untuk memenuhi kebutuhan dasarnya. Mereka sangat terdampak oleh pandemi COVID-19 sehingga berhak mendapatkan bansos tanpa perlu mengikuti pelatihan peningkatan kompetensi.

Permasalahan lain yang dihadapi oleh tenaga kerja Indonesia salah satunya adalah sulitnya memenuhi persyaratan sertifikasi untuk beberapa profesi. Dengan adanya pelatihan yang dapat memberikan sertifikat tentu saja sangat membantu tenaga kerja terutama yang bekerja dalam bidang jasa. Pelatihan yang seperti ini dari sisi harga mungkin dapat lebih mahal dibandingkan pelatihan lainnya karena harus dilakukan dalam beberapa tahap. Akan tetapi, seringkali 
pelatihan yang dilakukan secara satu arah saja dan tidak ada tugas dan umpan balik dari Lembaga pelatihan sehingga sulit untuk mengetahui apakah materi yang disampaikan benar-benar berguna atau tepat sasaran. Jika hal ini dapat dipastikan maka tujuan untuk meningkatkan kompetensi dari tenaga kerja dapat tercapai.

Dana Program KP mencapai Rp. 20 triliun dengan target penerima 5.6 juta jiwa. Adapun prioritas yang menjadi sasaran ialah karyawan yang terkena PHK, pekerja informal dan pelaku UMKM yang terdampak Covid-19 (Nurhadi, 2020). Dengan dana tersebut, harga yang ditetapkan oleh Lembaga pelatihan wajib kurang dari 1 juta rupiah dan dapat ditawarkan di berbagai platform digital. Harga yang ditawarkan relatif beragam mulai dari $\mathrm{Rp} 150.000$ - Rp 1.000.000, seharusnya harga pelatihan dapat lebih murah jika tidak memberikan sertifikat profesional. Dengan harga yang lebih murah, diharapkan semakin banyak pelatihan yang diambil oleh tenaga kerja sesuai dengan kebutuhan mereka. Hal ini juga terkait dengan anggaran yang disediakan untuk Program KP yang mencapai triliun rupiah. Menurut pendapat Fadli Zon biaya pelatihan daring menyedot anggaran hingga $\mathrm{Rp} 5.6$ triliun terlalu berlebihan. Sebagai pembanding, dia menerangkan, anggaran TVRI dan RRI dalam APBN 2020 itu masing-masing hanya $\mathrm{Rp} 1.2$ triliun dan $\mathrm{Rp}$ 1.3 triliun. Jika anggaran itu diserahkan kepada TVRI dan RRI maka seluruh target Program KP dapat terpenuhi. Jika TVRI atau RRI diserahkan untuk memproduksi siaran program pelatihan keterampilan dan kewirausahaan, seluruh masyarakat bisa mengakses. Bahkan, mereka tak perlu beli pulsa, kuota, atau memiliki ponsel Android untuk bisa mengakses. Triliunan anggaran yang digelontorkan melalui Program KP memang layak untuk terus diperhatikan dan dikaji ulang oleh pemerintah, agar supaya efektivitas dari realisasi program tersebut juga membawa pengaruh besar pada setiap sendi kehidupan di sektor-sektor masyarakat kecil dengan perbaikan prosedur tentunya (Predianto \& Khoirurrosyidin, 2020).

Wijayanti \& Humardhiana (2020) menyatakan bahwa diperlukan pengabdian masyarakat dengan memberikan pelatihan Branding Strategy tanpa biaya ini diadakan untuk membantu masyarakat dalam memulai memasarkan produknya yang berupa barang ataupun jasa. Karena produk yang memiliki pasar kecil memiliki peluang yang lebih besar untuk memasarkan produknya dengan lebih fleksibel. Program KP ini bisa jadi sebagai salah satu realisasi janji kampanye Presiden Jokowi yang ingin menciptakan sumber daya manusia yang mampu bersaing dalam dan luar negeri dan melatih keterampilan individu. Program ini adalah program yang sangat baik terutama di era digitalisasi ini yang memberikan kesempatan setiap orang untuk belajar secara online. Selain itu, multiplier efek dari program ini tidak hanya bagi penerima insentif tapi juga bagi Lembaga pelatihan, platform digital, bahkan para "calo" yang membantu mendaftarkan.

Program ini merupakan kebijakan dari sisi penawaran tenaga kerja dan merupakan solusi jangka pendek dari sisi membantu masyarakat yang terkena dampak pandemi Covid 19. Program ini dapat sejalan dengan program DUDI (Dunia Usaha Dunia Industri) untuk meningkatkan keterampilan tenaga kerja yang sesuai dengan kebutuhan dunia industri. Sedangkan dari sisi permintaan tenaga kerja, memerlukan kebijakan yang berbeda untuk mampu menyerap penawaran tenaga kerja dan atau menciptakan lapangan pekerjaan sendiri.

Tantangan bagi tenaga kerja Indonesia adalah $63 \%$ lulusan pendidikan formalnya 
tidak sesuai dengan kebutuhan dunia kerja, bonus demografi yang akan dimiliki Indonesia pada tahun 2030-2040, dan mismatch antara lapangan pekerja yang tersedia dan tenaga kerja yang tersedia, tingginya angka pengangguran muda, dan budaya pelatihan di Indonesia yang masih rendah. Hal ini karena pelatihan dan pendidikan bukan merupakan prioritas utama perusahaan, di sinilah fungsi Program KP untuk mengisi kekosongan sebagai jembatan sebelum memulai karier maupun pindah agar ada peningkatan keterampilan dan relevansi untuk bekerja maupun berwirausaha. Sejumlah manfaat yang didapat dari Program KP yakni: (1) Membantu meringankan biaya pelatihan yang ditanggung pekerja dan perusahaan; (2) Mengurangi biaya dalam mencari informasi mengenai pelatihan; (3) Mendorong kebekerjaan seseorang melalui pengurangan missmatch; (4) Menjadi komplemen dari Pendidikan Formal; dan (5) Membantu daya beli masyarakat yang terdampak penghidupannya akibat Covid-19 (Nurhadi, 2020).
Terkait dengan tujuan komplemen pendidikan formal, perlu dinilai efektifitasnya melalui adanya tindak lanjut atau progress setelah pelatihan seperti apa. Adanya semacam monitoring evaluasi (monev) dan laporan tindak lanjut dari pelatihan yang diambil. Walaupun hasil survei meningkatkan kompetensi dan keahlian mereka, akan tetapi perlu adanya tindakan nyata bagi yang belum bekerja. Jika dilihat dari kesesuaian antara lowongan pekerjaan dan program yang dibutuhkan sudah sesuai. Misalnya untuk lowongan terbesar yaitu penjualan dan pemasaran sudah ditawarkan pelatihan terkait hal ini serta menjadi pelatihan yang paling diminati oleh masyarakat. Pelatihan yang ditawarkan dalam rangka meningkatkan kompetensi angkatan kerja memang memiliki sisi kualitas dari supply angkatan kerja. Tetapi, selama permintaan terhadap tenaga kerja tidak ditingkatkan, lapangan kerja tidak diciptakan, persoalan pengangguran akan terus menghantui perekonomian, apalagi ini terjadi di tengah pandemi Covid-19.
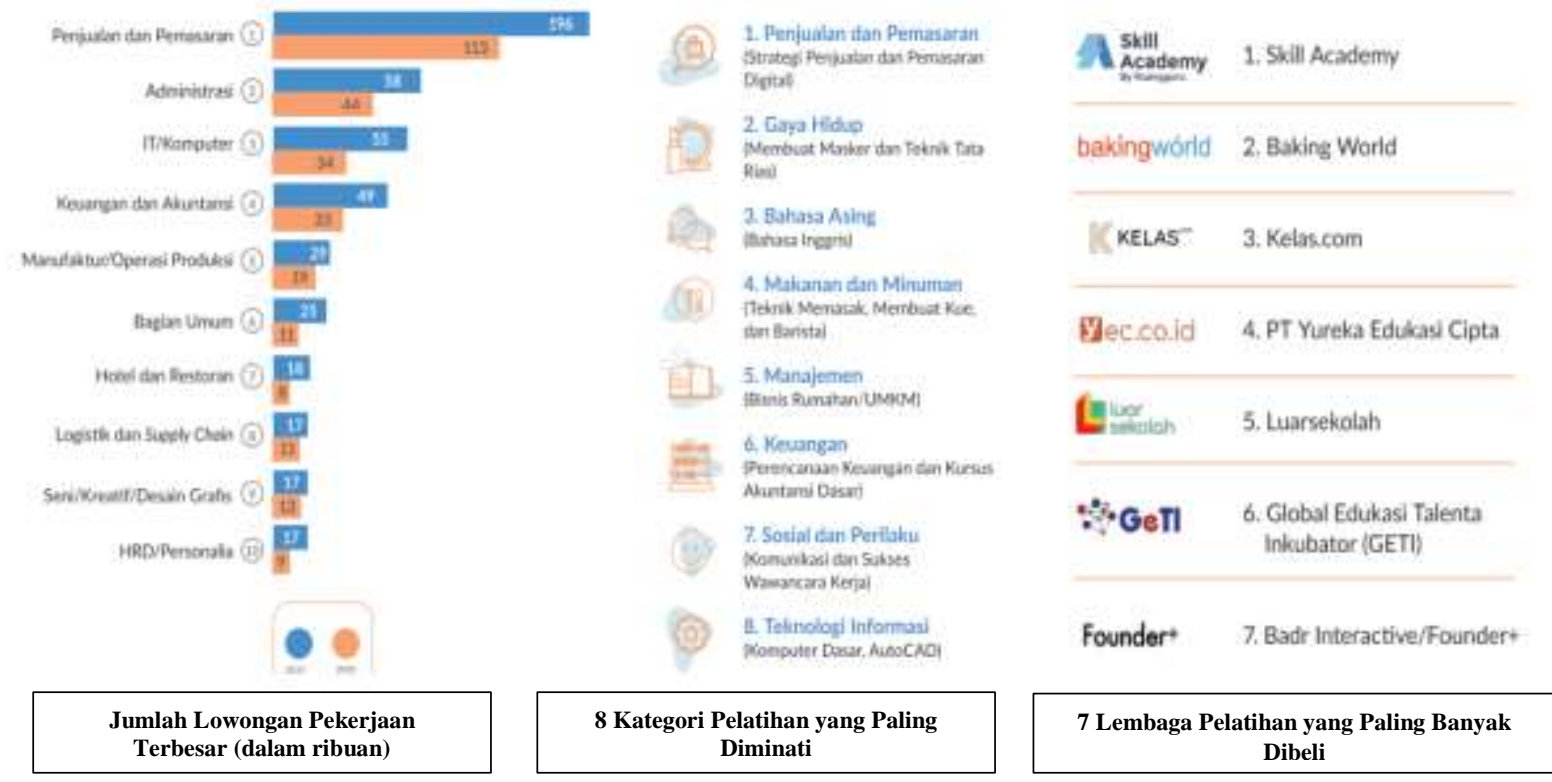

Sumber: (Kemenko Perekonomian, 2020)

Gambar 4. Jumlah Lowongan Pekerjaan Terbesar (dalam ribuan) 
Faktor-faktor yang Memengaruhi Keputusan Mendaftar Kartu Prakerja

Hasil survei Sakernas 2020 memasukkan pertanyaan terkait dengan kartu Prakerja setelah program ini berjalan efektif 2 bulan. Walaupun mungkin tidak dapat menggambarkan sepenuhnya program ini akan tetapi, data primer yang terbaru yang dapat diakses penuh adalah dari survei ini. Berdasarkan hasil survei Sakernas, diketahui bahwa $22.60 \%$ responden yang tahu mengenai Prakerja dan hanya sekitar $6.20 \%$ yang mendaftar (11 107 orang). Artinya, tidak semua orang mendaftar Program KP walaupun mereka mengetahuinya.

Tabel 2. Deskriptif Responden yang Tahu, Mendaftar, dan Lolos Program KP

\begin{tabular}{|c|c|c|c|c|}
\hline \multirow{2}{*}{$\begin{array}{c}\text { Mengetahui } \\
\text { program } \\
\text { kartu } \\
\text { prakerja? }\end{array}$} & \multicolumn{4}{|c|}{ Mendaftar Prakerja atau Tidak } \\
\hline & $\begin{array}{c}\text { Tidak } \\
\text { tahu/tidak } \\
\text { menjawab }\end{array}$ & Daftar & Tidak & Total \\
\hline \multirow{2}{*}{ Ya } & 0.00 & $11,107.00$ & $168,154.00$ & $179,261.00$ \\
\hline & 0.00 & 6.20 & 93.80 & 100.00 \\
\hline \multirow{2}{*}{ Tidak } & $613,941.00$ & 0.00 & 0.00 & $613,941.00$ \\
\hline & 100.00 & 0.00 & 0.00 & 100.00 \\
\hline \multirow{2}{*}{ Total } & $613,941.00$ & $11,107.00$ & $168,154.00$ & $793,202.00$ \\
\hline & 77.40 & 1.40 & 21.20 & 100.00 \\
\hline
\end{tabular}

\begin{tabular}{|c|c|c|c|c|}
\hline \multirow{2}{*}{$\begin{array}{l}\text { Mengetahui } \\
\text { program } \\
\text { kartu } \\
\text { prakerja? }\end{array}$} & \multicolumn{4}{|c|}{ Lolos seleksi program kartu prakerja atau tidak } \\
\hline & $\begin{array}{c}\text { Tidak } \\
\text { Tahu/tidak } \\
\text { menjawab }\end{array}$ & Lolos & Tidak & Total \\
\hline \multirow{2}{*}{$\begin{array}{c}\text { Tidak } \\
\text { tahu/tidak } \\
\text { menjawab }\end{array}$} & 613,941 & 0 & 0 & 613,941 \\
\hline & 100 & 0 & 0 & 100 \\
\hline \multirow[t]{2}{*}{ Ya } & 0 & 1,503 & 9,604 & 11,107 \\
\hline & 0 & 13.53 & 86.47 & 100 \\
\hline \multirow[t]{2}{*}{ Tidak } & 168,154 & 0 & 0 & 168,154 \\
\hline & 100 & 0 & 0 & 100 \\
\hline \multirow[t]{2}{*}{ Total } & 782,095 & 1,503 & 9,604 & 793,202 \\
\hline & 98.6 & 0.19 & 1.21 & 100 \\
\hline
\end{tabular}

Sumber: Sakernas, 2020

Masyarakat yang mendaftar kartu pilihan jawaban di survei. Akan tetapi, perlu Prakerja bertujuan untuk meningkatkan juga diketahui faktor-faktor lain baik keterampilan kerja (49\%), mendapatkan demografi maupun non-demografi alasan insentif (28\%), hanya coba-coba (13\%), seseorang mendaftar atau tidak. Faktor apa mengisi waktu luang (5\%), serta karena yang menjadi pertimbangan ketika pendaftarannya gratis (3\%). Alasan-alasan memutuskan untuk mendaftar. tersebut bersifat kualitatif sesuai dengan

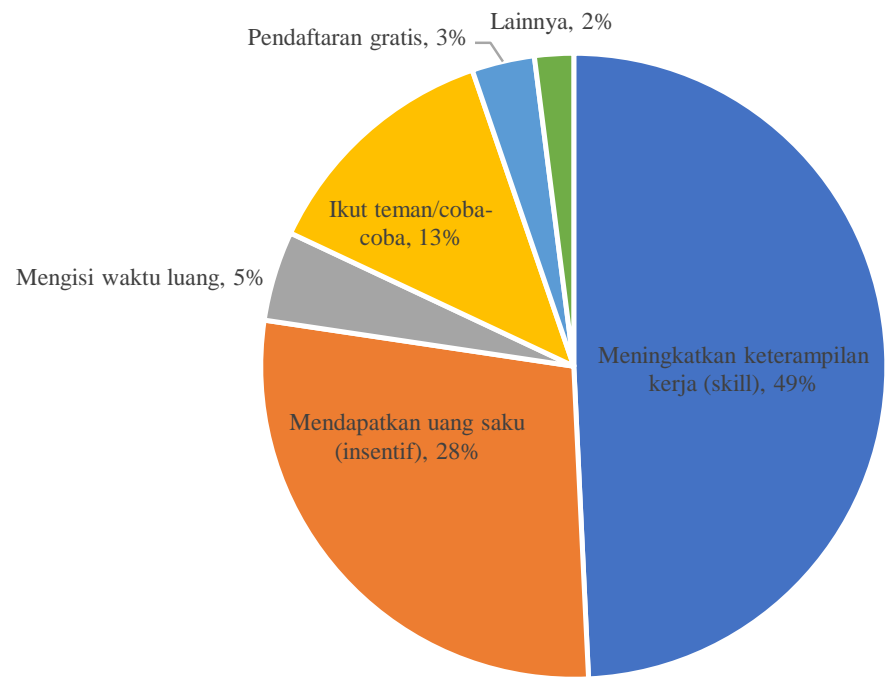

Sumber: Sakernas, 2020

Gambar 5. Alasan Responden Mendaftar Kartu Prakerja 
Berdasarkan hasil analisis logit, dapat diketahui bahwa faktor-faktor yang memengaruhi keputusan seseorang untuk mendaftar atau tidak Program KP adalah jumlah jam kerja saat ini, pendapatan yang diperoleh, umur, sedang melakukan training, status pekerjaan (formal atau informal), menggunakan internet, keinginan menambah jam atau tidak, sedang mempersiapkan usaha baru/tidak, perubahan pendapatan dan jam kerja dibandingkan Februari 2020, serta tingkat pendidikan. Hasil yang sama juga dijabarkan oleh Lusianingrum et al., (2020) yang menyebutkan bahwa faktor-faktor yang memengaruhi keputusan mengikuti pelatihan adalah faktor budaya, sosial, pribadi, dan teknologi. Walaupun demikian, tidak semua masyarakat dapat merasakan kesempatan tersebut, karena keterbatasan kuota per gelombangnya dan diterapkannya sistem seleksi. Ditambah lagi dengan gugatan dari beberapa pemerhati publik yang intinya menyayangkan efektivitas dana triliunan untuk diaplikasikan pada Program KP, karena tidak efisien (Predianto \& Khoirurrosyidin, 2020).

Tabel 3. Faktor-faktor yang Memengaruhi Keputusan Mendaftar Prakerja atau Tidak.

\begin{tabular}{|c|c|c|c|c|}
\hline Variable & Odds Ratio & Std. Err. & $\mathbf{z}$ & $\mathbf{P}>\mathbf{Z}$ \\
\hline Jam kerja & 1.0098 & 0.0012 & 8.2300 & $0.0000 * *$ \\
\hline Pendapatan & 1.0000 & 0.0000 & -11.3700 & $0.0000 * *$ \\
\hline Umur & 0.9606 & 0.0021 & -18.2600 & $0.0000 * *$ \\
\hline \multicolumn{5}{|l|}{ Pendidikan } \\
\hline SMA-SMK & 2.0774 & 0.1269 & 11.9700 & $0.0000 * *$ \\
\hline Diploma-PT & 2.3563 & 0.1675 & 12.0600 & $0.0000 * *$ \\
\hline \multicolumn{5}{|l|}{ Training } \\
\hline Sedang Mengikuti Training & 1.2454 & 0.1171 & 2.3300 & $0.0200 *$ \\
\hline \multicolumn{5}{|l|}{ Formal_informal } \\
\hline Formal & 0.7624 & 0.0337 & -6.1300 & $0.0000 * *$ \\
\hline \multicolumn{5}{|l|}{ Jam_kerja_bertambah } \\
\hline $\mathrm{Ya}$ & 1.5106 & 0.0677 & 9.2100 & $0.0000 * *$ \\
\hline \multicolumn{5}{|l|}{ Pendapatan_kerja_bertambah } \\
\hline Ya & 0.7747 & 0.0658 & -3.0100 & $0.0030 * *$ \\
\hline \multicolumn{5}{|l|}{ Usaha_baru } \\
\hline Mempersiapkan Usaha Baru & 2.2100 & 0.3000 & 5.8400 & $0.0000 * *$ \\
\hline \multicolumn{5}{|l|}{ Internet } \\
\hline Menggunakan Internet & 1.6466 & 0.0760 & 10.8100 & $0.0000 * *$ \\
\hline Konstanta & 0.2323 & 0.0283 & -11.9700 & $0.0000 * *$ \\
\hline
\end{tabular}

Hasil analisis logit menunjukkan bahwa responden dengan jam kerja 1 jam diestimasi/diperkirakan lebih berpeluang mendaftar 1.0098 kali lebih mungkin, dibandingkan responden dengan jam kerja 1 jam lebih sedikit. Semakin banyak jumlah jam kerjanya semakin tinggi peluang untuk mendaftar. Begitu pula dengan variabel pendapatan responden dengan nilai odds ratio yang sama dengan variabel jam kerja. Nilai koefisien regresi logistik dari umur adalah 0.9606 (bernilai positif), artinya semakin tua/bertambah umur seseorang, maka semakin meningkat probabilitas mendaftar kartu Prakerja. Sedangkan peluang orang yang bekerja di sektor formal untuk mendaftar adalah 0.7624 kali lebih mungkin 
dibandingkan yang bekerja di sektor informal.

Responden yang sedang merencanakan usaha baru diestimasi/diperkirakan berpeluang untuk mendaftar 2.2100 kali lebih mungkin dibandingkan yang sedang tidak merencanakan usaha. Responden dengan kategori inilah yang seharusnya menjadi target kartu Prakerja dengan membantu mereka memberikan pelatihan-pelatihan yang dibutuhkan untuk mempersiapkan usahanya. Besarnya kemungkinan ini mirip dengan responden yang memiliki tingkat pendidikan SMA-SMK dan Diploma PT dibandingkan dengan responden lulusan SMP kebawah. Artinya, semakin tinggi tingkat pendidikan seseorang semakin tinggi kemungkinan untuk mendaftar. Responden yang lulusan SMA-SMK diperkirakan berpeluang untuk mendaftar 2.0774 Program KP 2.0774 kali lebih tinggi dibandingkan yang lulusan SDSMP. Sedangkan responden dengan lulusan Diploma-PT berpeluang lebih tinggi 2.3563 kali mungkin dibandingkan lulusan lainnya.

Bagi mereka yang sedang mempersiapkan usaha kemudian memperoleh bantuan Program KP, menjadi hal yang tepat jika mereka dapat mengakses kredit untuk modal. Program KP dapat diselaraskan dengan program fasilitas pinjaman Kredit Usaha Rakyat (KUR) sebagai modal usaha. Pemerintah telah memberikan subsidi bunga pinjaman kredit usaha rakyat (KUR) dan menaikkan plafon pinjaman KUR tanpa agunan. Berdasarkan Peraturan Menteri Nomor 6 Tahun 2020 tentang perlakuan khusus bagi penerima kredit usaha rakyat disebutkan bahwa adanya perlakuan khusus bagi penerima KUR terdampak pandemi. Diantaranya memberikan kemudahan dan/ atau keringanan pembayaran angsuran pokok dan bunga/marjin. Bagi calon penerima KUR terdampak pandemi akan mendapatkan relaksasi pemenuhan persyaratan administrasi dalam proses pengajuan KUR, seperti Nomor Induk Berusaha (NIB) atau surat keterangan usaha mikro dan kecil yang diterbitkan oleh pejabat yang berwenang dan/atau surat keterangan yang dipersamakan lainnya, NPWP, dokumen agunan tambahan, dan/atau dokumen administrasi lainnya. Serta relaksasi pemenuhan berupa penundaan sementara penyampaian dokumen administrasi sampai dengan berakhirnya masa kedaruratan kesehatan masyarakat yang ditetapkan oleh pemerintah.

Agak sulit mengharapkan uang yang diperoleh dari Program KP sebagai modal usaha sehingga dengan adanya skema baru KUR Khusus yang terdampak pandemi dapat membantu untuk membuka usaha. Sebaiknya ada link antara Program KP dengan KUR sehingga peserta yang sudah mendapatkan pelatihan dan dinilai bagus dapat diarahkan untuk mendapatkan modal melalui skema KUR (prioritas). Mereka akan dibantu tidak hanya modal tapi juga dibimbing misalnya selama 3 tahun sampai usahanya stabil. Bimbingan ini dapat bekerja sama dengan Kementerian Sosial dan UMKM.

Dari sisi kemudahan akses yang dicerminkan penggunaan internet untuk bekerja, responden yang terbiasa memanfaatkan internet untuk bekerja lebih berpeluang untuk mendaftar 1.6466 kali lebih tinggi dibandingkan yang tidak. Program KP merupakan yang sepenuhnya bersifat online mulai dari pengumuman, pendaftaran, pelatihan, dan pembagian insentif sehingga seseorang yang terbiasa dengan internet kemungkinan lebih mudah mendapatkan informasi.

Selama pandemi Covid-19, pemerintah memberlakukan pembatasan dan peraturan terkait pekerjaan apa saja yang masih boleh dan tidak boleh beroperasi, serta beberapa sektor saja yang bisa bekerja dari rumah atau Work From Home (WFH). Artinya, lapangan 
kerja dan kesempatan kerja pun akan semakin kecil. Pemerintah perlu memberikan stimulus terhadap perusahaan atau pengusaha agar setidaknya menekan angka PHK yang berujung pada naiknya jumlah pengangguran (Consuello, 2020). Sehingga program ini dilakukan dari dua sisi yaitu permintaan penawaran tenaga kerja, berdampak jangka panjang dengan adanya penambahan lapangan kerja dan peningkatan kualitas tenaga kerja, serta mengurangi pengangguran.

Hasil survei BPS (2021) menyebutkan bahwa terdapat 19.10 juta orang $(9.30 \%$ penduduk usia kerja) yang terdampak Covid19. Terdiri dari pengangguran karena Covid19 (1.62 juta orang), Bukan Angkatan Kerja (BAK) karena Covid-19 (0.65 juta orang), sementara tidak bekerja karena Covid-19 (1.11 juta orang), dan penduduk bekerja yang mengalami pengurangan jam kerja karena Covid-19 (15.72 juta orang). Sedangkan penerima Program KP sampai pada gelombang ke-21 adalah sebanyak 5.9 juta orang. Artinya masih ada sekitar 13.2 juta tenaga kerja yang terkena dampak Covid tapi belum mendapatkan pelatihan/bantuan dari Program KP. Jika anggaran program sebesar $\mathrm{Rp} 20$ triliun dapat digunakan untuk menambah jumlah tenaga kerja yang mendapatkan pelatihan akan lebih baik. Salah satu caranya dengan menurunkan biaya/harga pelatihan sehingga dengan biaya yang sama, jumlah penerima menjadi lebih banyak. PMO dapat memilih Lembaga Pelatihan yang menawarkan harga lebih murah, kualitas bagus, jenis pelatihan yang lebIh beragama dan dapat diaplikasikan langsung di dunia kerja atau usaha.

\section{SIMPULAN DAN SARAN}

\section{Simpulan}

Banyak masyarakat yang memberikan sentimen negatif terhadap Program KP setelah 1 tahun pelaksanaannya terutama terkait dengan jenis pelatihan dan pendaftaran. Terkait dengan jenis pelatihan dan persyaratan yang lebih rinci lagi sehingga untuk peserta yang tidak lolos dapat mengetahui alasannya. Akan tetapi, hasil ini harus dikaji lebih lanjut terutama pengkategorian kata kunci sentimen negatif dan positif. Faktor-faktor yang memengaruhi keputusan seseorang untuk mendaftar kartu Prakerja adalah jumlah jam kerja saat ini, pendapatan yang diperoleh, umur, sedang melakukan training, status pekerjaan (formal atau informal), menggunakan internet, keinginan menambah jam atau tidak, sedang mempersiapkan usaha baru/tidak, perubahan pendapatan dan jam kerja dibandingkan Februari 2020, serta tingkat pendidikan. Kategori responden yang berpeluang paling tinggi untuk mendaftar Program KP adalah yang berpendidikan Diploma sampai Perguruan Tinggi (S1-S3). Faktor-faktor lain yang juga tinggi peluang untuk mendaftar adalah berpendidikan SMA-SMK, sedang mengikuti training, sedang mempersiapkan usaha baru, menggunakan internet untuk bekerja, dan jam kerjanya bertambah.

\section{Saran}

1. Sentimen negatif masih muncul di beberapa isu terkait dengan jenis pelatihan dan pendaftaran. Sehingga PMO perlu memperbaiki cara penyebaran informasi mengenai persyaratan dan pendaftaran. Hal ini untuk mencegah adanya pertanyaan dari masyarakat terkait mengapa mereka tidak bisa mendaftar atau tidak lolos Program KP.

2. Pelatihan yang ditawarkan bisa lebih murah harganya untuk memberikan kesempatan lebih banyak pelatihan yang diikuti dan menjangkau lebih banyak penerima dengan anggaran yang ada. Begitu pula dengan isu jenis pelatihan 
yang sebaiknya lebih banyak yang menyediakan sertifikat profesional.

3. Kedepannya, sebaiknya program Prakerja bersifat jangka panjang sehingga insentif tidak hanya digunakan untuk konsumsi tapi lebih banyak sebagai modal awal usaha.

4. Penelitian menggunakan data yang diolah sebelumnya oleh pihak lain, untuk kedepannya dapat digunakan data yang dicrawling sendiri untuk memastikan ketepatan pengkategorian sentimen positif, negatif, dan netral. Selain itu, dapat dilakukan survei yang mirip dengan Sakernas untuk mendapatkan data yang lebih update terkait kartu Prakerja.

\section{DAFTAR PUSTAKA}

Alan, K. M. A., Altman, Y., \& Roussel, J. 2008. Employee Training Needs and Perceived Value of Training in the Pearl River Delta of China: A Human Capital Development Approach. Journal of European Industrial Training, 32(1), 1931.

Anggraini, W., Utami, M., Berlianty, J., \& Sellya, E. (2021). Klasifikasi Sentimen Masyarakat Terhadap Kebijakan Kartu Prakerja di Indonesia. Faktor Exacta, 13(4), 255-261.

https://doi.org/10.30998/faktorexacta.v1 3i4.7964

Arwildayanto, Suking, A., \& Sumar, Tune Sumar, S.Pd., M. P. (2018). Analisis Kebijakan Pendidikan Kajian Teoritis, Eksploratif Dan Aplikatif. In Kebijakan Publik.

Consuello, Y. (2020). Analisis Efektifitas

Kartu Pra-kerja di Tengah Pandemi Covid-19. Buletin Hukum Dan Keadilan, 4(1), 93-100. http://journal.uinjkt.ac.id/index.php/adal ah/article/view/15479

Handayani, A. D., \& Rachman, A. (2020).
Dampak Pandemi COVID-19 Terhadap Motif dan Tren Penelusuran Informasi Kartu Prakerja di Indonesia. Empower: Jurnal Pengembangan http://www.syekhnurjati.ac.id/jurnal/ind ex.php/empower/article/view/7187

Kemenko Perekonomian. (2020). Laporan Manajemen Pelaksana Program Kartu Prakerja Tahun 2020. 1-39. https://static-assetcdn.prakerja.go.id/www/ebookreporting/Buku-Prakerja-Fix.pdf

Lusianingrum, F P W, \& ... (2020). Faktor Penentu Keputusan Mengikuti Pelatihan Daring pada Wanita Pemilik Kartu Prakerja. ...: Jurnal Inovasi Bisnis. http://ejournal.polbeng.ac.id/index.php/I BP/article/view/1537

Lusianingrum, Farah Putri Wenang, Affifatusholihah, L., \& Putri, S. I. (2020). Faktor Penentu Keputusan Mengikuti Pelatihan Daring pada Wanita Pemilik Kartu Prakerja. Inovbiz: Jurnal Inovasi Bisnis, 8(2), 175. https://doi.org/10.35314/inovbiz.v8i2.15 37

Nurhadi, W. (2020). Implementasi Kebijakan Program Kartu Prakerja Di Tengah Pandemi Covid-19. Journal of Political Science, May, 0-10.

Olssen, W., Codd, J., and O'neil, A. (1994). Education policy. In The Thai economy in transition. https://doi.org/10.4337/9781788113526. 00034

Predianto, T., \& Khoirurrosyidin. (2020). Mengkaji Upaya Pemerintah Melalui Program Kartu Prakerja dalam Perspektif Pemberdayaan di Masa Pandemi Covid-19. Journal of Government and Political Studies, 3(2).

Rawie, Y., \& Samputra, P. L. (2020). Analisis Cost and Effectivity Program Kartu Prakerja di Indonesia. Journal, 
$5(2)$,

$118-139$.

https://journal.uny.ac.id/files/journals/22

Jurnal Manajemen Pendidikan UNY, /articles/32430/submission/review/3243

0-85288-1-RV.pdf 02, 112408 .

Taufiqurakhman. (2014). Kebijakan Publik. In Fakultas Ilmu Sosial dan Ilmu Politik

Siregar, A. P., \& Oktaviana, N. (2020). Universitas Moestopo Beragama (Pers).

Realokasi Kartu Pra Kerja Dalam

Wijayanti, R. I., \& Humardhiana, A. (2020).

Mendukung Intensifikasi Sektor

Optimalisasi Program Kartu Prakerja

Pertanian. AGRISAINTIFIKA: Jurnal Dengan Pelatihan Branding Strategy.

Ilmu-Ilmu Pertanian, 4(1), 1. https://doi.org/10.32585/ags.v4i1.843

Sutapa, M. (2008). Kebijakan Pendidikan Dimasejati: Jurnal Pengabdian .... http://www.syekhnurjati.ac.id/jurnal/ind ex.php/dimasejati/article/view/6645

Dalam Perspektif Kebijakan Publik. 


\section{LAMPIRAN}

\section{Lampiran 1. Gelombang Pendaftaran Program KP}

1. Gelombang 1: 11 April 2020

2. Gelombang 2: 21 April 2020

3. Gelombang 3: 27 April 2020

4. Gelombang 4: 4 Agustus 2020

5. Gelombang 5: 15 Agustus 2020

6. Gelombang 6: 27 Agustus 2020

7. Gelombang 7: 3 September 2020

8. Gelombang 8: 10 September 2020

9. Gelombang 9: 17 September 2020

10. Gelombang 10: 26 September 2020

11. Gelombang 11: 2 November 2020

12. Gelombang 12: 23 Februari -26 Februari 2021

13. Gelombang 13: 4 Maret-7 Maret 2021

14. Gelombang 14: 11 Mare-14 Maret 2021

15. Gelombang 15: 18 Maret-21 Maret 2021

16. Gelombang 16: 25 Maret-28 Maret 2021

17. Gelombang 17: 1 Juni-7 Juni 2021

Lampiran 2. Analisis Deskriptif Variabel yang Dianalisis

\begin{tabular}{lrrrrr}
\hline Variable & Obs & Mean & Std. Dev. & Min & Max \\
\hline R27B & 179261 & .062 & .241 & 0 & 1 \\
R16A & 179261 & 25.041 & 22.406 & 0 & 168 \\
Income & 179261 & 1471758.3 & 2552719.4 & 0 & $1.050 \mathrm{e}+08$ \\
Married & 179261 & .617 & .486 & 0 & 1 \\
K6 & 179261 & 34.92 & 13.144 & 15 & 98 \\
R6E & 179261 & .042 & .2 & 0 & 1 \\
Formal Informal & 124791 & .589 & .492 & 0 & 1 \\
Internet & 124791 & .547 & .498 & 0 & 1 \\
Tambah jam & 124791 & .212 & .409 & 0 & 1 \\
R22B & 179261 & .015 & .123 & 0 & 1 \\
Deltaincome & 33557 & .079 & .269 & 0 & 1 \\
Deltajam & 40395 & .088 & .284 & 0 & 1 \\
Smp & 179261 & .249 & .432 & 0 & 1 \\
Smasmk & 179261 & .474 & .499 & 0 & 1 \\
Pt & 179261 & .277 & .448 & 0 & 1 \\
Pendidikan3 & 176313 & 2.046 & .718 & 1 & 3 \\
\hline
\end{tabular}




\section{Lampiran 3. Hasil Bot Score Kartu Prakerja yang Bersumber dari Twitter}
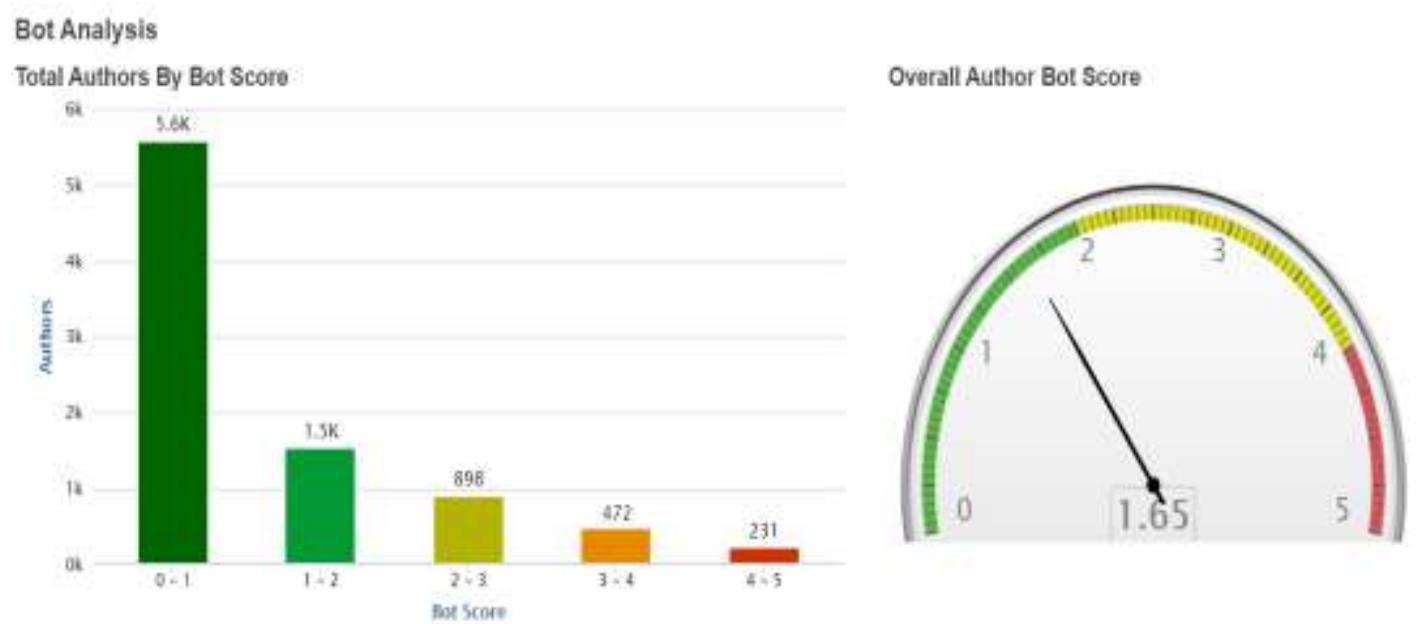

Lampiran 4. Wordcloud Pencarian Terkait Prakerja

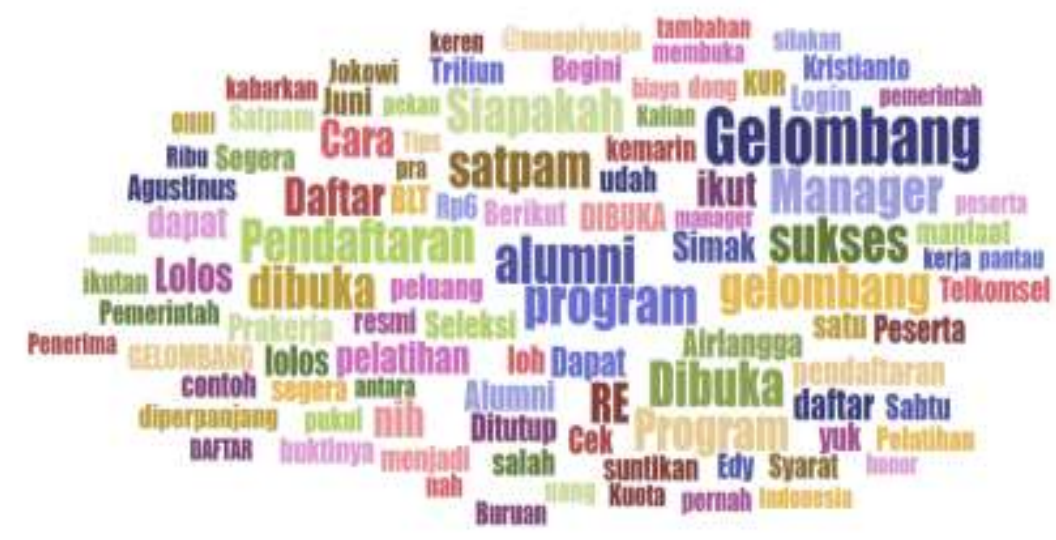

\section{Lampiran 5. Contoh Pelatihan Prakerja}

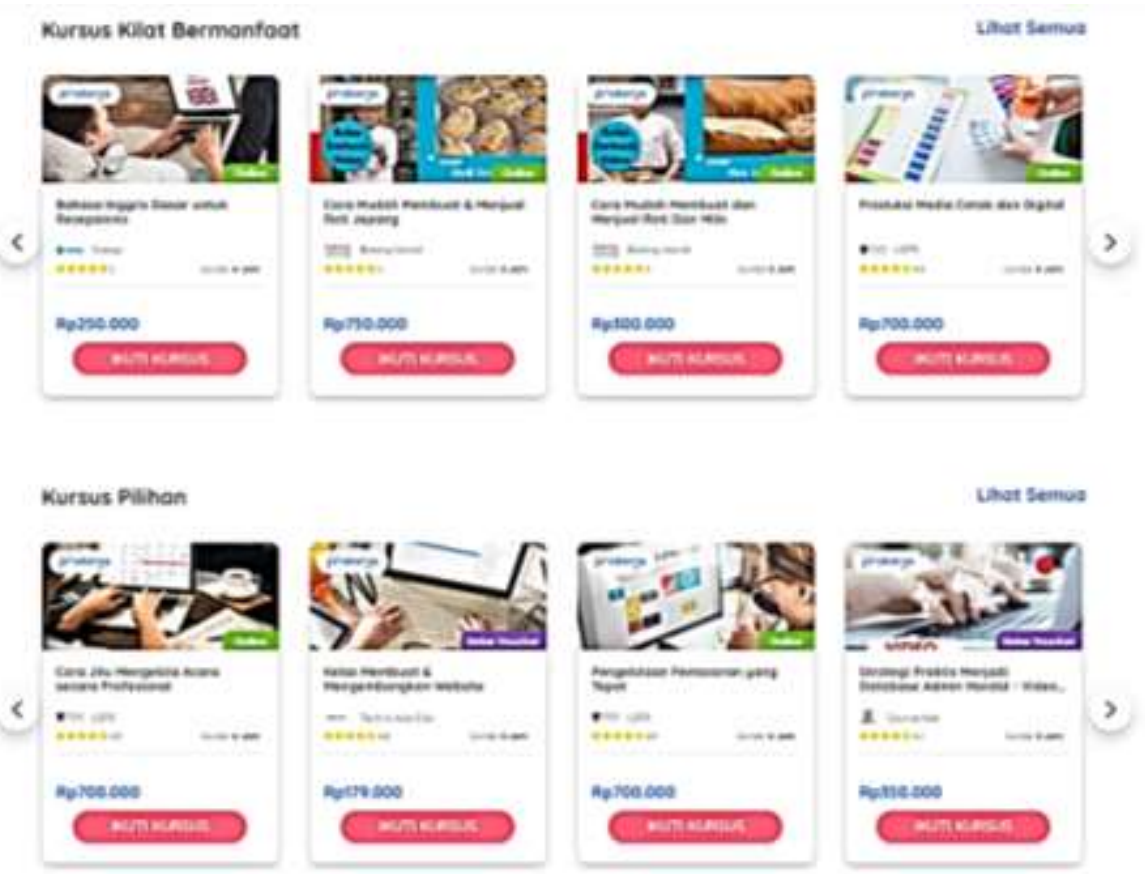


Cums 3 langksh buat pilih kursus kamu
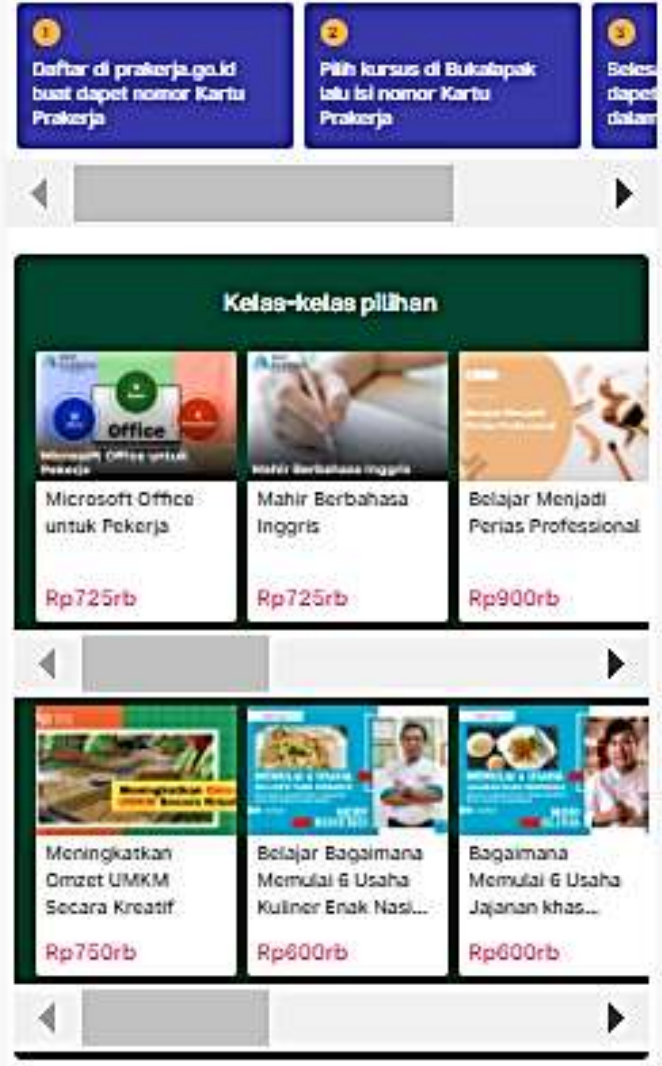
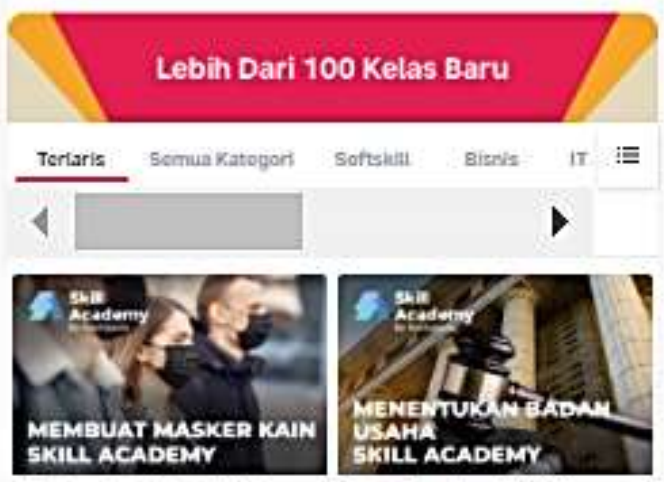

Membuat don Mernual Masker Kan Msiswon Virus Corona

Rp215rb

$$
\pm=.9 \text { Rp175rb }
$$

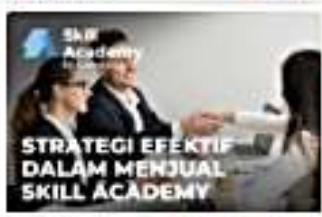

Strategi Etcktf Untuk Menjual Apapun Dengan Mudah

Rp250rb

$$
\text { * } 4.9 \text { Rpug5rb }
$$

t 4.9

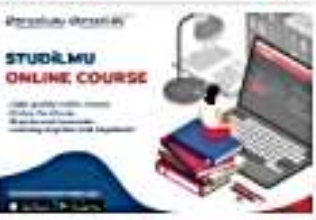

Pelatinan bagi Pemiltk Utana Kecit
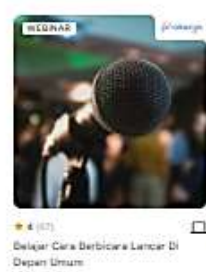

Ap 175000

- vorfore
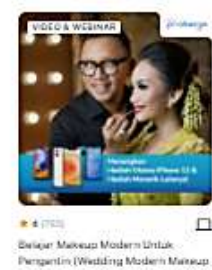

by temer tsed

Rp 500.0000
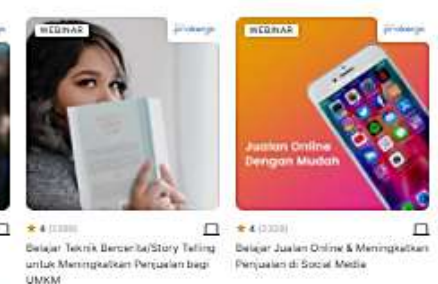

a

逢 $9 \mathrm{p} 250.000$

7 menticm

国 Ap 430.000

12

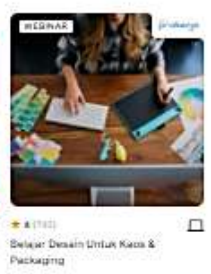

I0] Ap 450.000

图

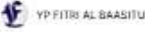
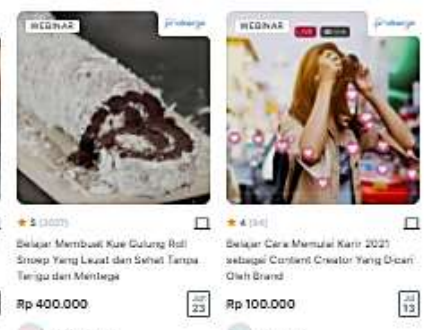

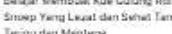

Ap 400.000

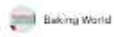

- varfore

\section{Kelas Tanpa Webinar}
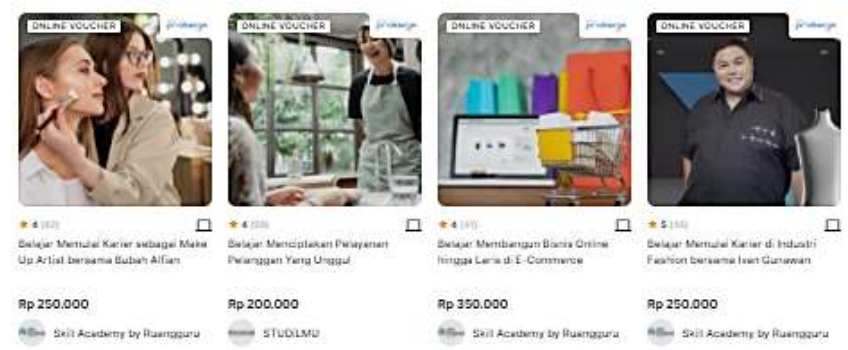


\section{Kelas Populer}

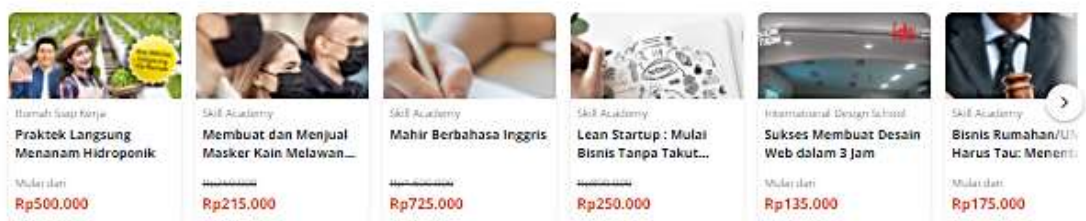

\section{Lembaga Pelatihan Pilihan}

\begin{tabular}{|c|c|c|c|}
\hline 幽 Hoxkiva & LE Luarsekolath & $x=$ Sxill Acadenty & I Rumiah Siapp Keria \\
\hline IS Kelasscom & $\alpha$ studiLMU & $=$ Daking World & - Carillrum \\
\hline
\end{tabular}

\section{Tata Boga}

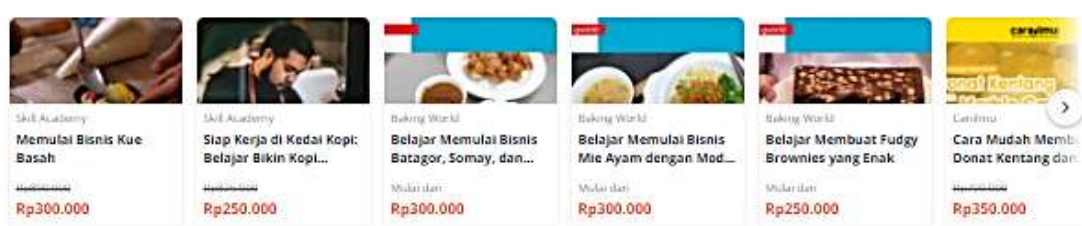

Pengembangan Diri

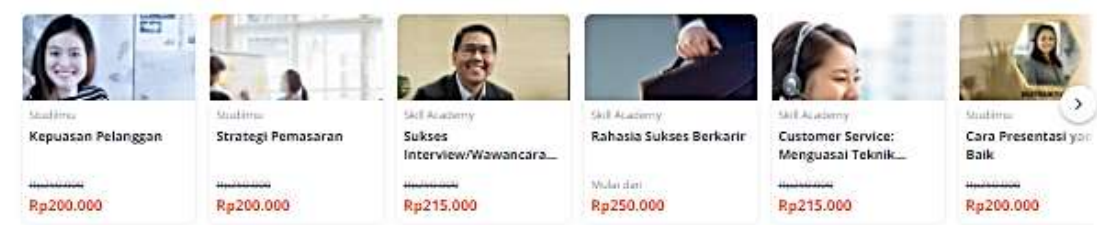

Bisnis

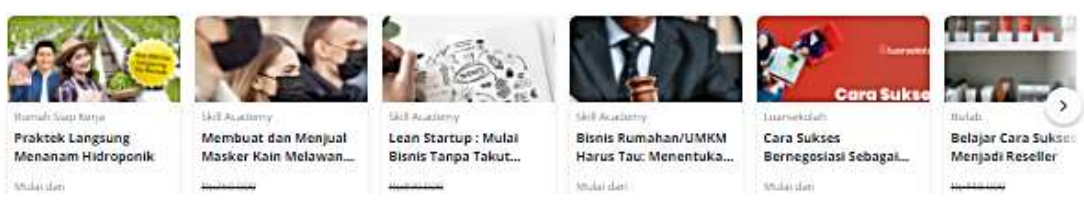

Program Kartu Prakerja
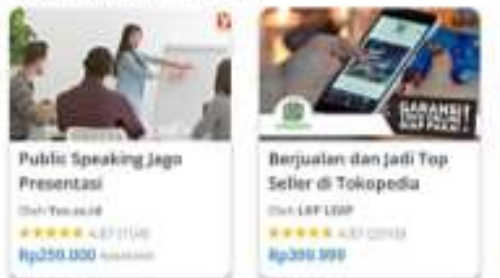

Aemualundentafi Top Selier \& Tokopeda

$$
\begin{aligned}
& \text { Selier s Tokipes } \\
& \text { suivion }
\end{aligned}
$$

Notirum

basume

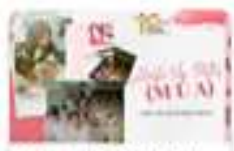

Mase up Ariscimua jed Solusi llivnis Capet

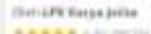

hasooso -

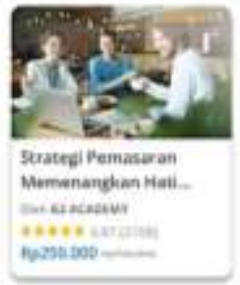

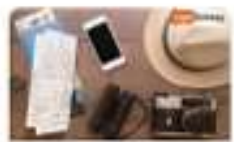

Inelish Laming: Merjad Teur ciede. the hemenomeres ayias.600

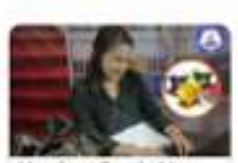

Vembuat Desein Mell das Kass Meregunasa.

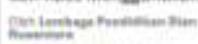

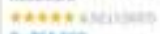
4yasstow
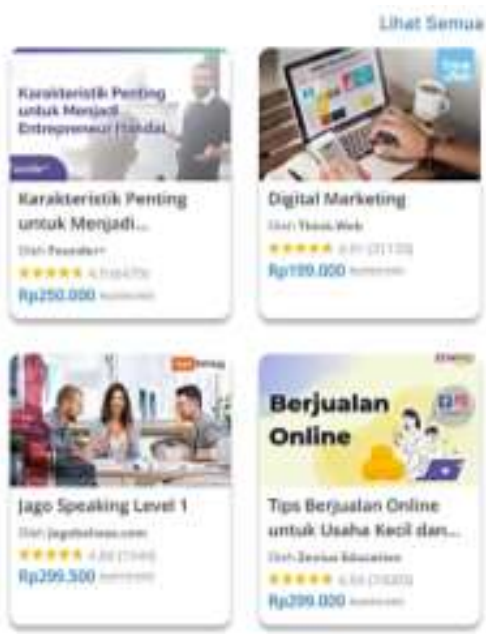


\section{Lampiran 6. Contoh Tweet dan Re-tweet}
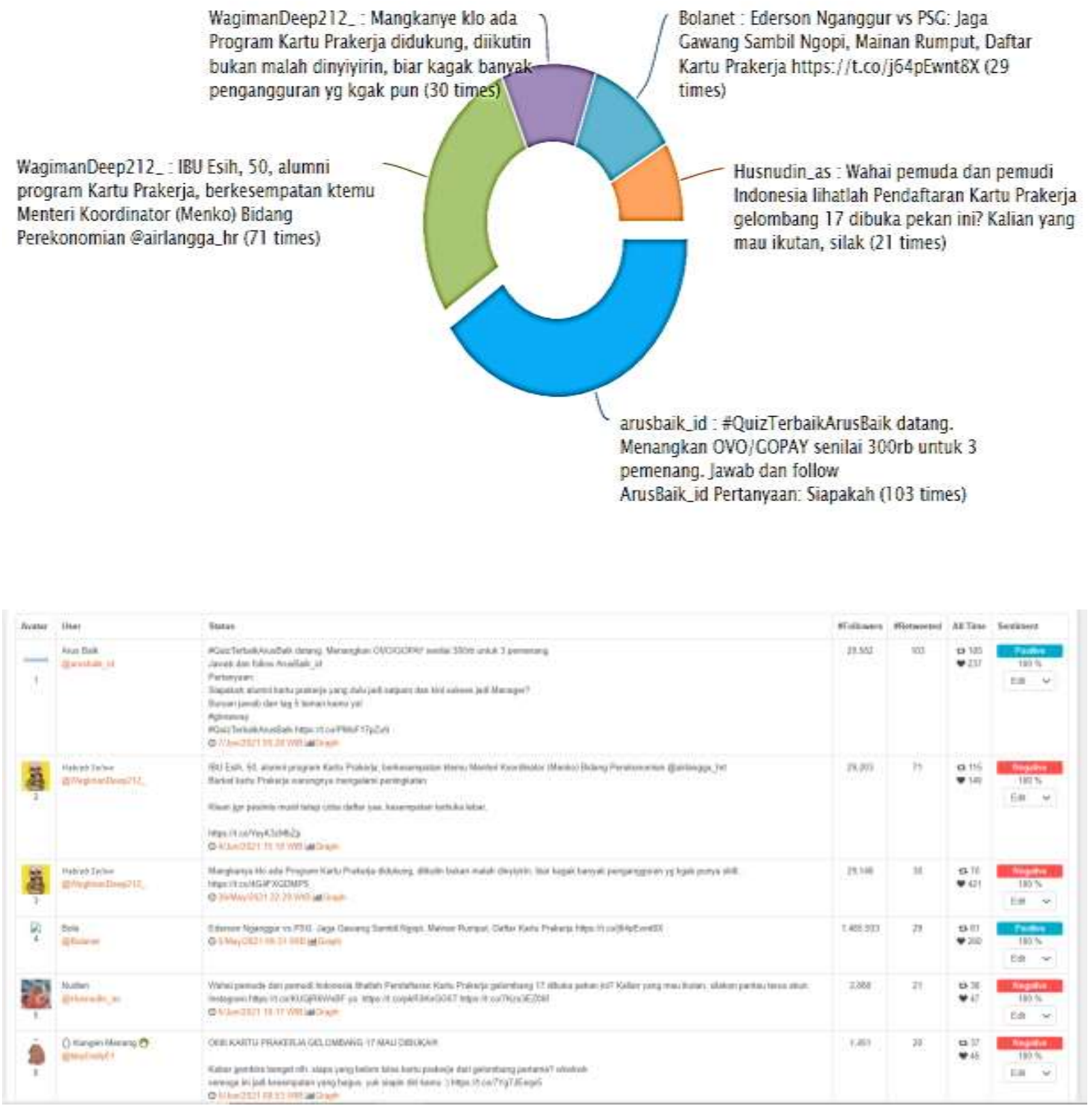